\title{
9. SEDIMENTATION IN THE VICINITY OF LEG 92 DRILL SITES: STUDIES OF SITE SURVEY CORES 1
}

\author{
Margaret Leinen and Amy Graybeal, Graduate School of Oceanography, \\ The University of Rhode Island, Narragansett ${ }^{2}$
}

\begin{abstract}
Surveys of the areas surrounding the sites drilled on the $\operatorname{Leg} 9219^{\circ} \mathrm{S}$ transect showed that sedimentation at all except the oldest site is dominated by calcium carbonate deposition. The sediments in the area of the oldest site, west of the Austral Fracture Zone, are being deposited beneath the calcium carbonate compensation depth and are dominated by terrigenous and metal-rich hydrogenous and hydrothermal sediments. The noncarbonate sediments in all of the areas east of the Austral Fracture Zone are dominated by hydrothermal sediment similar in composition to that presently being deposited at the East Pacific Rise. Although no biogenic microfossils were present in smear slides of the sediment, geochemical partitioning suggests that a remnant signal of siliceous biogenic deposition may be preserved, especially in gravity core (GC) 8, which was collected from a high heat flow zone near Site 600 . The siliceous sediment may also result from the deposition of amorphous hydrothermal silica from the higher concentrations of pore water $\mathrm{SiO}_{2}$ characteristic of the upwelling waters. Sedimentation on the broad plateaus that characterize each area is quite uniform and suggests that sites on these plateaus will be broadly representative of pelagic sedimentation in the area.
\end{abstract}

\section{INTRODUCTION}

Four areas forming a transect to the west of the East Pacific Rise (EPR) at $19^{\circ} \mathrm{S}$ (Fig. 1) were surveyed before Leg 92 to determine whether ridge flank hydrothermal processes are presently active at the sites and whether these processes have influenced the sites in the past. In addition, the surveys provided information for a geophysical, geochemical, and sedimentological framework for the Leg 92 drill sites. Sediment cores were collected at each of the four surveyed sites (Table 1) to look for chemical precipitates from present or past hydrothermal activity, to determine whether there have been changes in the rates at which such phases accumulated, and to evaluate the uniformity of regional patterns of sedimentation.

The criteria used to choose the areas to be surveyed were relatively smooth topography and uniform sediment cover with little rock outcrop, characteristics thought necessary for ridge flank hydrothermal advection through sediments instead of at outcrops. The transect was placed at $19^{\circ} \mathrm{S}$ because the region is one of low biological productivity, where hydrothermal material in the sediments is not reduced or remobilized by organic diagenesis (Bender et al., in press). In addition, areas were chosen that showed minimal evidence of redeposition. The sites on the $19^{\circ} \mathrm{S}$ transect formed at one of the fastest-spreading portions of the EPR. It has been proposed that the intensity of hydrothermal activity and the accumulation of hydrothermal phases is directly related to spreading rate (Boström et al., 1973; Boström, 1974). If so, the sites should have been subjected to intense ridge crest

\footnotetext{
${ }^{1}$ Leinen, M., Rea, D. K., et al., Init. Repts. DSDP, 92: Washington (U.S. Govt. Printing Office).

2 Address: Graduate School of Oceanography, The University of Rhode Island, Narragansett, RI 02882-1197.
}

hydrothermal activity and should have high accumulation rates of hydrothermal sediment.

Specific coring targets within each area were chosen after Seabeam swath mapping (Lonsdale, this volume) and multipenetration heat flow surveys (Hobart et al., 1982). The cores represent most depositional environments in each surveyed area and span the range of heat flow indicated by the surveys. Because the main dredge winch failed during the survey, all cores were gravity cores rather than piston cores.

\section{METHODS}

The calcium carbonate content of freeze-dried samples was determined by using a carbonate pressure bomb method similar to that used routinely for analysis on the Glomar Challenger. The results listed (Table 2) are the average of two determinations. The precision of the pressure bomb analyses is roughly $\pm 2 \mathrm{wt} . \% \mathrm{CaCO}_{3}$ (Dunn, 1980). The carbonate contents measured by the bomb are diluted by sea salt from interstitial waters. Therefore, all carbonate contents listed in Table 2 were corrected and are reported on a salt-free basis.

Salt contents of samples (Table 3) were determined to correct geochemical data for dilution by sea salt. Freeze-dried samples were weighed and resuspended in $5 \mathrm{ml}$ of deionized water to dissolve salt from interstitial waters. After the suspension was centrifuged to remove the sediment, the chloride content of the salt solution was determined by $\mathrm{AgCl}$ titration using an automated chloridometer. Sea salt contents were calculated from the chlorinity of the solution by assuming that salinity $=1.80655 \times$ chlorinity. Duplicate determinations indicated a precision of $\pm 5 \%$ of measured value or generally about $\pm 0.4 \mathrm{wt} . \%$ salt. Water contents for the sediments (Table 3 ) were calculated from the dry and wet weight of sediment samples in fixed-volume plastic sampling tubes.

Sediments chosen for chemical analysis were prepared by a procedure modified from Bernas (1968). Samples were freeze dried (in order to obtain a fine powder without grinding dried sample), dissolved in $\mathrm{HF}$ and aqua regia in Teflon-lined pressure bombs, and neutralized with boric acid. The samples were analyzed for $\mathrm{Mg}, \mathrm{Al}, \mathrm{Si}, \mathrm{Ca}, \mathrm{Mn}$, $\mathrm{Fe}, \mathrm{Cu}, \mathrm{Zn}$, and $\mathrm{Ba}$ by flame atomic absorption spectroscopy (AAS) and for $\mathrm{Co}$ and $\mathrm{Ni}$ by flameless AAS. The precision of duplicate determinations averaged \pm 2 to $\pm 5 \%$ of measured values for major elements and \pm 5 to $\pm 10 \%$ of measured values for trace elements. Comparison of our analyses with U.S. Geological Survey rock standards AGV-1 and GSP-1 indicates that systematic errors are not present. 


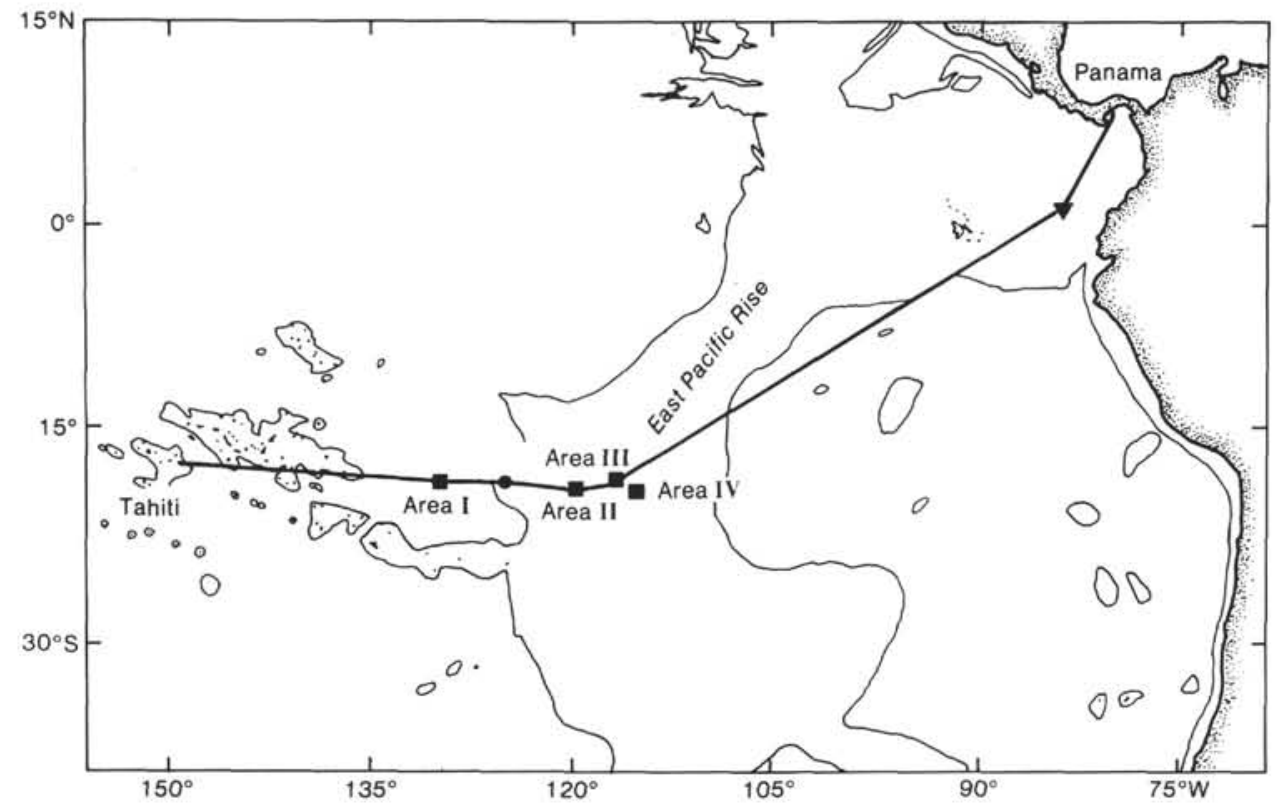

Figure 1. Location of areas surveyed by Ariadne II (squares), Site 598 (circle), and Hole 504B (triangle).

Table 1. Ariadne II core locations.

\begin{tabular}{ccccc}
\hline Core & $\begin{array}{c}\text { Latitude } \\
(\mathrm{S})\end{array}$ & $\begin{array}{c}\text { Longitude } \\
(\mathrm{W})\end{array}$ & $\begin{array}{c}\text { Water } \\
\text { depth } \\
(\mathrm{m})\end{array}$ & $\begin{array}{c}\text { Length } \\
(\mathrm{cm})\end{array}$ \\
\hline Area I & & & & \\
GC 1 & $18^{\circ} 48.60^{\prime}$ & $129^{\circ} 44.86^{\prime}$ & 4130 & 181 \\
Area II & & & & \\
& & & & \\
GC 2 & $19^{\circ} 25.23^{\prime}$ & $119^{\circ} 49.58^{\prime}$ & 3654 & 116 \\
GC 3 & $19^{\circ} 26.07^{\prime}$ & $119^{\circ} 51.65^{\prime}$ & 3670 & \\
GC 4 & $19^{\circ} 25.02^{\prime}$ & $119^{\circ} 48.18^{\prime}$ & 3570 & 123 \\
GC 5 & $19^{\circ} 24.29^{\prime}$ & $119^{\circ} 52.65^{\prime}$ & 3680 & 74 \\
GC 6 & $19^{\circ} 23.54^{\prime}$ & $119^{\circ} 48.33^{\prime}$ & 3600 & 165 \\
& & & & \\
Area III & & & & \\
& & & & \\
GC 7 & $18^{\circ} 55.68^{\prime}$ & $116^{\circ} 50.56^{\prime}$ & 3450 & 303 \\
GC 8 & $18^{\circ} 55.64^{\prime}$ & $116^{\circ} 50.45^{\prime}$ & 3350 & 228 \\
GC 9 & $18^{\circ} 55.73^{\prime}$ & $116^{\circ} 51.74^{\prime}$ & 3430 & 312 \\
GC 10 & $18^{\circ} 58.65^{\prime}$ & $116^{\circ} 51.36^{\prime}$ & 3310 & 323 \\
GC 11 & $18^{\circ} 55.71^{\prime}$ & $116^{\circ} 50.47^{\prime}$ & 3370 & 311 \\
Area IV & & & & \\
& & & & \\
GC 12 & $19^{\circ} 29.65^{\prime}$ & $114^{\circ} 57.22^{\prime}$ & 3280 & 91 \\
GC 13 & $19^{\circ} 29.77^{\prime}$ & $114^{\circ} 57.64^{\prime}$ & 3435 & 124 \\
GC 14 & $19^{\circ} 29.85^{\prime}$ & $114^{\circ} 56.62^{\prime}$ & 3390 & 281 \\
GC 15 $19^{\circ} 29.68^{\prime}$ & $114^{\circ} 58.91^{\prime}$ & 3300 & 324 \\
GC 16 & $19^{\circ} 29.73^{\prime}$ & $114^{\circ} 58.19^{\prime}$ & 3300 & 374 \\
\hline & & & & \\
\hline
\end{tabular}

\section{GEOLOGIC SETTING OF SEDIMENTS FROM SITE SURVEY AREAS}

\section{Area I (Site 597)}

Area I (Fig. 2), on 28.6-Ma crust (Rea, this volume), was the oldest area surveyed, and Site 597 was drilled within it. The crust was generated at the fossil Mendoza Rise and is in a region of moderate heat flow. Air gun and Seabeam surveys of the area showed sediment-draped abyssal hills with less than $100 \mathrm{~m}$ of bathymetric relief. The area chosen for detailed heat flow and pore water surveys had so little relief (20 to $40 \mathrm{~m}$ ) that it was not surveyed completely using Seabeam. The first core from the area, Ariadne II gravity core (GC) 1, consisted entirely of unfossiliferous brown clay. No further cores were taken in the area because (1) the heat flow was very uniform, (2) none of the heat flow or pore water data from the site survey showed any evidence of fluid advection (Hobart et al., 1982), and (3) the air gun lines showed acoustically transparent sediment of nearly uniform thickness over the 5-by-7-km area surveyed (Lonsdale, this volume).

\section{Area II (Site 599)}

Area II was surveyed with Seabeam (Fig. 3). The 7.8$\mathrm{Ma}$ area (Rea, this volume) is bounded on the east by a southward-plunging abyssal-hill ridge with about $150 \mathrm{~m}$ of relief and on the west by a basin with a NE-SW trend. Between the ridge and the basin is a broad $(8-\mathrm{km})$ flat area with $<40 \mathrm{~m}$ of relief. Multipenetration heat flow surveys showed that the area has moderate heat flow with no evidence of the vertical advection of pore fluids or present-day hydrothermal activity. Four cores were recovered, Ariadne II GC 2 and GC 4 to 6 (Fig. 3). All cores were mixtures of nannofossil ooze and brown clay. The pore water data (Bender et al., in press) show no evidence of reducing conditions due to organic diagenesis.

\section{Area III (Sites 600 to 602)}

Area III, which is located on 4.6-Ma crust (Fig. 4), also consists of a relatively flat, sediment-covered plateau with $<40 \mathrm{~m}$ of relief. The area is bounded on the east by a plunging abyssal-hill ridge and on the west by a valley. The plateau is roughly $6 \mathrm{~km}$ wide and has fairly uniform heat flow and sediment cover. The site survey found no evidence of fluid advection on the plateau. There was, however, heat flow and pore water evidence for hydrothermal fluid advection in the thin sediment $(<10 \mathrm{~m})$ at the north end of the abyssal-hill ridge, where 
Table 2A. Chemistry of Ariadne II sediments. All values are corrected for dilution by salt from pore waters.

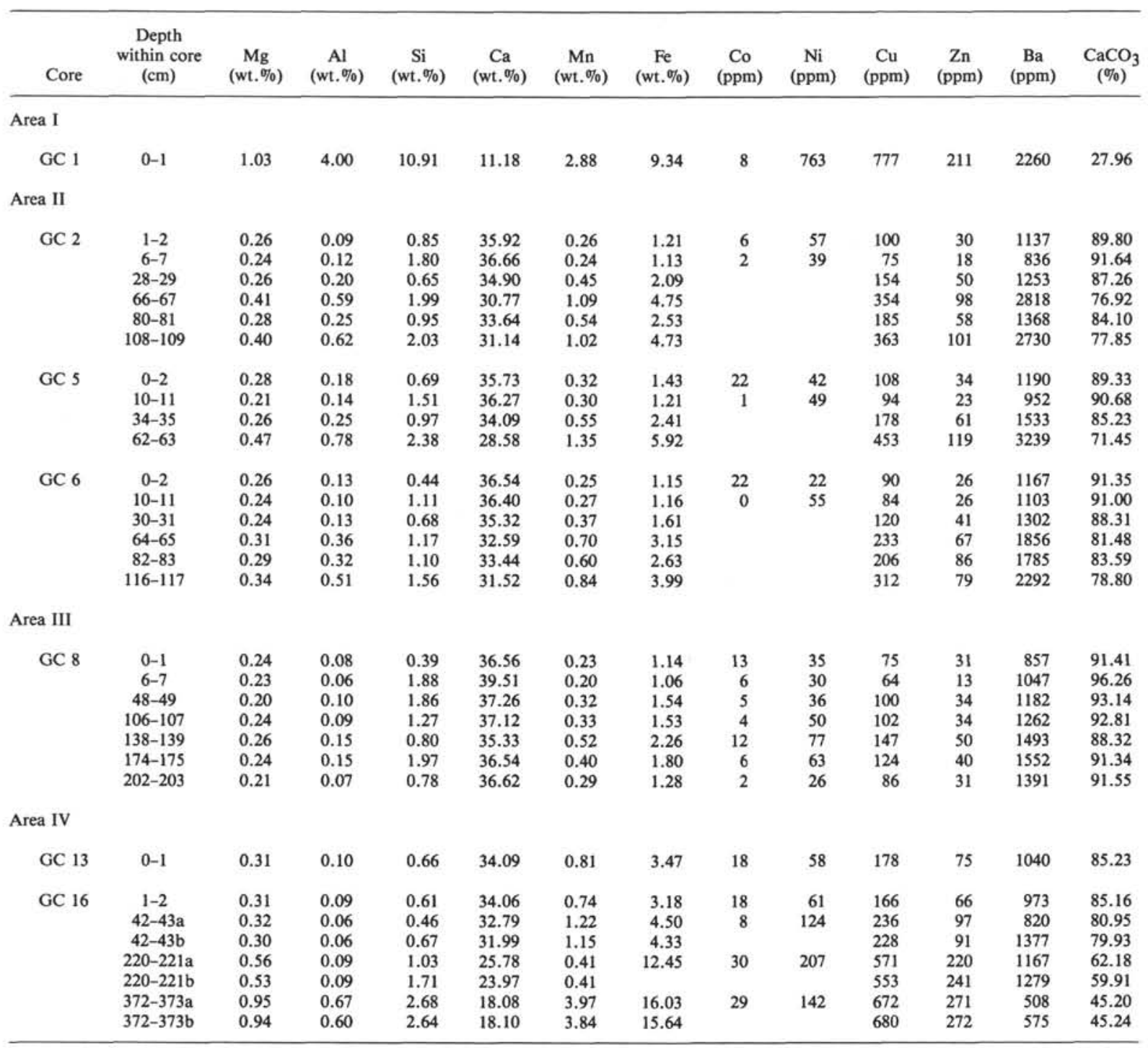

the ridge plunges beneath the sediment, and in the thin sediment cover on the ridge to the south (Hobart et al., 1982; Bender et al., 1985).

Five cores were taken in Area III, Ariadne II GC 7 to 11 (Fig. 4). All sediments were mixtures of nannofossil ooze and brown clay. There was no evidence in the pore water chemistry of reducing conditions from organic diagenesis. Sediment cores from ridge flank hydrothermal structures in the Galapagos Mounds (Corliss et al., 1978) and the Mariana mounds (Leinen and Anderson, 1981; Maris et al., in press) show macroscopic evidence of hydrothermal activity such as lithification, fractures filled with secondary sediments, or Mn crusts. None of the cores from Area III showed any such evidence of ridge flank hydrothermal activity.

\section{Area IV}

Area IV, located on 1.8-Ma crust, was a broad sediment-covered area about 5 by $5 \mathrm{~km}$ that lay between two abyssal-hill ridges (Fig. 5). The area had about 40 to $60 \mathrm{~m}$ of bathymetric relief. The air gun records from the area indicate that although the abyssal-hill ridges were draped with thin sediment cover, most sediment was ponded in areas about 1 to $2 \mathrm{~km}$ wide between the abyssalhill ridges. The heat flow was moderate but showed no evidence of advection. The four cores from the area (Ariadne II GC 12 to 16) contained nannofossil ooze and clay. This area was not drilled on Leg 92 because the site survey found no evidence of off-axis hydrothermal activity and because the ponded sediments would not have accumulated at rates typical of hydrothermal sedimentation.

\section{RESULTS}

\section{Sedimentation Rates in Site Survey Areas}

The sedimentation rates along the $19^{\circ} \mathrm{S}$ transect are extremely low, and radiometric dating techniques produced ambiguous results. Siliceous microfossils were not present in the sediments, and magnetostratigraphy could not be used to evaluate differences in sedimentation rates because the amount of terrigenous material in the cores is very small and the magnetic reversal signal is unsta- 
Table 2B. Chemistry of Ariadne II sediments. All values are corrected for dilution by salt from pore waters and are carbonate free.

\begin{tabular}{|c|c|c|c|c|c|c|c|c|c|c|c|}
\hline Core & $\begin{array}{l}\text { Depth } \\
\text { within core } \\
\text { (cm) }\end{array}$ & $\begin{array}{c}\mathrm{Mg} \\
\text { (wt.\%) }\end{array}$ & $\begin{array}{c}\mathrm{Al} \\
\text { (wt.\%) }\end{array}$ & $\underset{\text { (wt.\%) }}{\mathrm{Si}}$ & $\underset{\text { (wt.\%) }}{\mathrm{Mn}}$ & $\begin{array}{c}\mathrm{Fe} \\
\text { (wt.\%) }\end{array}$ & $\begin{array}{c}\text { Co } \\
(\mathrm{ppm})\end{array}$ & $\begin{array}{c}\mathrm{Ni} \\
(\mathrm{ppm})\end{array}$ & $\underset{(\mathrm{ppm})}{\mathrm{Cu}}$ & $\underset{(\mathrm{ppm})}{\mathrm{Zn}}$ & $\underset{\text { (wt.\%) }}{\mathrm{Ba}}$ \\
\hline \multicolumn{12}{|l|}{ Area I } \\
\hline GC 1 & $0-1$ & 1.42 & 5.56 & 15.14 & 3.99 & 12.97 & 11 & 1059 & 1079 & 293 & 0.31 \\
\hline \multicolumn{12}{|l|}{ Area II } \\
\hline GC 2 & $\begin{array}{c}1-2 \\
6-7 \\
28-29 \\
66-67 \\
80-81 \\
108-109\end{array}$ & $\begin{array}{l}2.55 \\
2.87 \\
2.04 \\
1.78 \\
1.76 \\
1.81\end{array}$ & $\begin{array}{l}0.88 \\
1.44 \\
1.57 \\
2.56 \\
1.57 \\
2.80\end{array}$ & $\begin{array}{r}8.33 \\
21.53 \\
5.10 \\
8.62 \\
5.97 \\
9.16\end{array}$ & $\begin{array}{l}2.55 \\
2.87 \\
3.53 \\
4.72 \\
3.40 \\
4.60\end{array}$ & $\begin{array}{l}11.86 \\
13.52 \\
16.41 \\
20.58 \\
15.91 \\
21.35\end{array}$ & $\begin{array}{l}59 \\
24\end{array}$ & $\begin{array}{l}559 \\
467\end{array}$ & $\begin{array}{r}980 \\
897 \\
1209 \\
1534 \\
1164 \\
1639\end{array}$ & $\begin{array}{l}294 \\
215 \\
392 \\
425 \\
365 \\
456\end{array}$ & $\begin{array}{l}1.11 \\
1.00 \\
0.98 \\
1.22 \\
0.86 \\
1.23\end{array}$ \\
\hline GC 5 & $\begin{array}{c}0-2 \\
10-11 \\
34-35 \\
62-63\end{array}$ & $\begin{array}{l}2.62 \\
2.25 \\
1.76 \\
1.65\end{array}$ & $\begin{array}{l}1.69 \\
1.50 \\
1.69 \\
2.73\end{array}$ & $\begin{array}{r}6.47 \\
16.20 \\
6.57 \\
8.34\end{array}$ & $\begin{array}{l}3.00 \\
3.22 \\
3.72 \\
4.73\end{array}$ & $\begin{array}{l}13.40 \\
12.98 \\
16.32 \\
20.74\end{array}$ & $\begin{array}{r}206 \\
11\end{array}$ & $\begin{array}{l}394 \\
526\end{array}$ & $\begin{array}{l}1012 \\
1009 \\
1205 \\
1587\end{array}$ & $\begin{array}{l}319 \\
247 \\
413 \\
417\end{array}$ & $\begin{array}{l}1.12 \\
1.02 \\
1.04 \\
1.13\end{array}$ \\
\hline GC 6 & $\begin{array}{c}0-2 \\
10-11 \\
30-31 \\
64-65 \\
82-83 \\
116-117\end{array}$ & $\begin{array}{l}3.01 \\
2.67 \\
2.05 \\
1.67 \\
1.77 \\
1.60\end{array}$ & $\begin{array}{l}1.50 \\
1.11 \\
1.11 \\
1.94 \\
1.95 \\
2.41\end{array}$ & $\begin{array}{r}5.09 \\
12.33 \\
5.82 \\
6.32 \\
6.70 \\
7.36\end{array}$ & $\begin{array}{l}2.89 \\
3.00 \\
3.17 \\
3.78 \\
3.66 \\
3.96\end{array}$ & $\begin{array}{l}13.29 \\
12.89 \\
13.77 \\
17.01 \\
16.03 \\
18.82\end{array}$ & & $\begin{array}{l}254 \\
611\end{array}$ & $\begin{array}{r}1040 \\
933 \\
1027 \\
1258 \\
1255 \\
1472\end{array}$ & $\begin{array}{l}301 \\
289 \\
351 \\
362 \\
524 \\
373\end{array}$ & $\begin{array}{l}1.35 \\
1.23 \\
1.11 \\
1.00 \\
1.09 \\
1.08\end{array}$ \\
\hline \multicolumn{12}{|l|}{ Area III } \\
\hline GC 8 & $\begin{array}{c}0-1 \\
6-7 \\
48-49 \\
106-107 \\
138-139 \\
174-175 \\
202-203\end{array}$ & $\begin{array}{l}2.79 \\
6.15 \\
2.92 \\
3.34 \\
2.23 \\
2.77 \\
2.49\end{array}$ & $\begin{array}{l}0.93 \\
1.60 \\
1.46 \\
1.25 \\
1.28 \\
1.73 \\
0.83\end{array}$ & $\begin{array}{r}4.54 \\
50.27 \\
27.11 \\
17.66 \\
6.85 \\
22.75 \\
9.23\end{array}$ & $\begin{array}{l}2.68 \\
5.35 \\
4.66 \\
4.59 \\
4.45 \\
4.62 \\
3.43\end{array}$ & $\begin{array}{l}13.27 \\
28.34 \\
22.45 \\
21.28 \\
19.35 \\
20.79 \\
15.15\end{array}$ & $\begin{array}{r}151 \\
160 \\
73 \\
56 \\
103 \\
69 \\
24\end{array}$ & $\begin{array}{l}407 \\
802 \\
525 \\
695 \\
659 \\
727 \\
308\end{array}$ & \begin{tabular}{r|}
873 \\
1711 \\
1458 \\
1419 \\
1259 \\
1432 \\
1018
\end{tabular} & $\begin{array}{l}361 \\
348 \\
496 \\
473 \\
428 \\
462 \\
367\end{array}$ & $\begin{array}{l}1.00 \\
2.80 \\
1.72 \\
1.76 \\
1.28 \\
1.79 \\
1.65\end{array}$ \\
\hline \multicolumn{12}{|l|}{ Area IV } \\
\hline GC 13 & $0-1$ & 2.10 & 0.68 & 4.47 & 5.48 & 23.49 & 122 & 393 & 1205 & 508 & 0.70 \\
\hline GC 16 & $\begin{array}{c}1-2 \\
42-43 \mathrm{a} \\
42-43 \mathrm{~b} \\
220-221 \\
220-221 \\
372-373 \\
372-373\end{array}$ & $\begin{array}{l}2.09 \\
1.68 \\
1.49 \\
1.48 \\
1.32 \\
1.73 \\
1.72\end{array}$ & $\begin{array}{l}0.61 \\
0.31 \\
0.30 \\
0.24 \\
0.22 \\
1.22 \\
1.10\end{array}$ & $\begin{array}{l}4.11 \\
2.41 \\
3.34 \\
2.72 \\
4.27 \\
4.89 \\
4.82\end{array}$ & $\begin{array}{l}4.99 \\
6.40 \\
5.73 \\
1.08 \\
1.02 \\
7.24 \\
7.01\end{array}$ & $\begin{array}{l}21.43 \\
23.62 \\
21.57 \\
32.92 \\
\\
29.25 \\
28.56\end{array}$ & $\begin{array}{r}121 \\
42 \\
79 \\
73\end{array}$ & $\begin{array}{l}411 \\
651 \\
547 \\
259\end{array}$ & $\begin{array}{l}1119 \\
1239 \\
1136 \\
1510 \\
1379 \\
1226 \\
1242\end{array}$ & $\begin{array}{l}445 \\
509 \\
453 \\
582 \\
601 \\
495 \\
497\end{array}$ & $\begin{array}{l}0.66 \\
0.43 \\
0.69 \\
0.31 \\
0.32 \\
0.09 \\
0.11\end{array}$ \\
\hline
\end{tabular}

ble. Nannofossils were present, and the nannofossil biostratigraphy (Table 4), combined with calcium carbonate correlations (Leinen, this volume), provides the only age control for the gravity cores. This stratigraphy indicates that the Pleistocene/Pliocene boundary lies between 1.0 $\mathrm{m}$ and $1.5 \mathrm{~m}$ in the Area II cores, between $1.5 \mathrm{~m}$ and $2.0 \mathrm{~m}$ in the Area III cores, and between $2.5 \mathrm{~m}$ and $3.0 \mathrm{~m}$ in the Area IV cores. These boundaries are consistent with the positions of the Pleistocene/Pliocene boundaries at the drilled sites. The biostratigraphy suggests a Pleistocene sedimentation rate of $0.7 \mathrm{~cm} / 10^{3} \mathrm{yr}$. in Area II, $1.0 \mathrm{~cm} / 10^{3} \mathrm{yr}$. in Area III, and $1.5 \mathrm{~cm} / 10^{3} \mathrm{yr}$. in Area IV.

A primary concern in any survey for drilling sites in pelagic sediments is the degree to which the sediments and sedimentation rates from a single drill site are representative of the area surrounding the drill site. Because the site survey cores were short and the sedimentation rates in the area were very low, our studies could not provide long, detailed records of sedimentation in the areas. Instead, we focused on the degree to which the fine-scale variations in sedimentation (i.e., 0.1 to $1 \mathrm{~m}$ ) could be correlated across the areas. Systematic variations in the concentration of calcium carbonate in Pleistocene and Pliocene sediments in the equatorial and subtropical Pacific result from basin-wide changes in the amount of dissolution of carbonate (e.g., Berger, 1973; Broecker and Broecker, 1974). The sedimentation in Areas II to IV is dominated by calcium carbonate, and in spite of the low sedimentation rates the calcium carbonate record can be correlated with equatorial Pacific records of carbonate variation (Leinen, this volume). Therefore, correlation of the variations in percent calcium carbonate in cores from each area provides a useful index of the uniformity of sedimentation.

Figure 6 shows the calcium carbonate contents of three cores from Area II plotted on a common depth scale. The carbonate contents of the sediments were analyzed at 2-cm intervals and show considerable fine-scale variation. Cores GC 5 and GC 6 were analyzed at sea and 
Table 3. Salt and water contents of site survey core samples used for geochemical analysis.

\begin{tabular}{|c|c|c|c|c|}
\hline Core & $\begin{array}{l}\text { Depth } \\
\text { within core } \\
\text { (cm) }\end{array}$ & $\begin{array}{l}\text { Water } \\
(\%)\end{array}$ & $\begin{array}{c}\text { Dry-bulk } \\
\text { density } \\
\left(\mathrm{g} / \mathrm{cm}^{3}\right)\end{array}$ & $\begin{array}{l}\text { Salt } \\
(\%)\end{array}$ \\
\hline \multicolumn{5}{|l|}{ Area I } \\
\hline GC 1 & $0-1$ & & & 5.95 \\
\hline \multicolumn{5}{|l|}{ Area II } \\
\hline GC 2 & $\begin{array}{c}1-2 \\
6-7 \\
28-29 \\
66-67 \\
80-81 \\
108-109\end{array}$ & $\begin{array}{l}52.56 \\
49.62 \\
46.64 \\
50.67 \\
46.32 \\
47.59\end{array}$ & $\begin{array}{l}0.752 \\
0.822 \\
0.810 \\
0.686 \\
0.838 \\
0.692\end{array}$ & $\begin{array}{l}3.81 \\
3.59 \\
3.21 \\
3.69 \\
3.13 \\
3.20\end{array}$ \\
\hline GC 5 & $\begin{array}{c}0-2 \\
10-11 \\
34-35 \\
62-63\end{array}$ & $\begin{array}{l}55.9 \\
50.9 \\
47.8 \\
52.7\end{array}$ & $\begin{array}{l}0.660 \\
0.747 \\
0.760 \\
0.736\end{array}$ & $\begin{array}{l}4.21 \\
3.32 \\
2.75 \\
3.55\end{array}$ \\
\hline GC 6 & $\begin{array}{c}0-2 \\
10-11 \\
30-31 \\
64-65 \\
82-83 \\
116-117\end{array}$ & $\begin{array}{l}54.2 \\
49.3 \\
48.1 \\
44.7 \\
46.2 \\
42.2\end{array}$ & $\begin{array}{l}0.626 \\
0.800 \\
0.876 \\
0.875 \\
1.009 \\
0.790\end{array}$ & $\begin{array}{l}4.36 \\
3.27 \\
2.97 \\
3.00 \\
3.26 \\
2.94\end{array}$ \\
\hline \multicolumn{5}{|l|}{ Area III } \\
\hline GC 8 & $\begin{array}{c}0-1 \\
6-7 \\
48-49 \\
106-107 \\
138-139 \\
174-175 \\
202-203\end{array}$ & $\begin{array}{l}52.6 \\
52.8 \\
48.6 \\
46.4 \\
48.6 \\
48.5 \\
43.9\end{array}$ & $\begin{array}{l}0.632 \\
0.749 \\
0.813 \\
0.789 \\
0.739 \\
0.721 \\
0.873\end{array}$ & $\begin{array}{l}3.68 \\
3.31 \\
2.85 \\
2.90 \\
2.81 \\
3.00 \\
2.64\end{array}$ \\
\hline \multicolumn{5}{|l|}{ Area IV } \\
\hline GC 13 & $0-1$ & 50.7 & 0.837 & \\
\hline GC 16 & $\begin{array}{c}1-2 \\
142-143 \\
220-221 \\
372-373\end{array}$ & $\begin{array}{l}48.5 \\
46.6 \\
64.2\end{array}$ & $\begin{array}{l}0.409 \\
0.756 \\
0.865 \\
0.452\end{array}$ & $\begin{array}{l}3.11 \\
3.45 \\
5.43\end{array}$ \\
\hline
\end{tabular}

have considerably higher variance, which is probably due to larger errors in weight determination at sea than in our shore laboratory. It is clear, however, that the primary feature of the carbonate curves (the drop in Ca$\mathrm{CO}_{3}$ concentration from roughly 90 to $70 \mathrm{wt} . \%$ ) occurs at the same depth in all of the cores $( \pm 2 \mathrm{~cm})$. The cores span the water depth range of the broad plateau in Area II and include a core close to the abyssal-hill ridge at the eastern margin of the area. In spite of the $80-\mathrm{m}$ water depth difference between the shallowest and deepest core, and the proximity to potential sources of redeposited sediments, the main features of the $\mathrm{CaCO}_{3}$ profiles are very similar. Although this similarity obviously cannot be extrapolated to the entire sediment column, it does indicate that pelagic sediment deposition on the plateau has been very uniform during the Pleistocene and Pliocene. Combined with the rather uniform sediment thickness and continuity of air gun reflectors, the data suggest that any site on the plateau in Area II would be representative of pelagic sedimentation in the area.

Although sedimentation on the plateaus between abyssal-hill ridges on the transect may be uniform, a com- parison of the nannofossil biostratigraphy for Sites 600 , 601 , and 602 in Area III indicates that there are large differences in sedimentation rate between sites in different settings: sedimentation rates on the abyssal-hill ridge in Area III (Site 600) were roughly half those on the plateau (Site 601).

\section{Physical Properties of Ariadne II Sediments}

The water contents and dry-bulk densities of the site survey cores were analyzed in detail to determine whether they were related to or affected by fluid advection through the sediments. The dry-bulk densities of unlithified deep-sea sediments are often a function of the calcium carbonate content (Mayer, 1970; Dymond and Veeh, 1975; Lyle and Dymond, 1976). This relationship exists because the density of calcium carbonate $(\rho=2.72 \mathrm{~g} /$ $\mathrm{cm}^{3}$ ) is much greater than that of clay (about $2.5 \mathrm{~g} / \mathrm{cm}^{3}$ ) and amorphous silica (about $2.2 \mathrm{~g} / \mathrm{cm}^{3}$ ). High water content in calcareous deep-sea sediments has also been related to high carbonate content (Mayer, 1980). In the Ariadne II cores, however, we found that the bulk densities and water contents were directly related to carbonate content only when the range of carbonate variation was very large (e.g., Fig. 7A). Cores with lower ranges showed a substantially weaker correlation between bulk density and carbonate content and between water content and carbonate content (e.g., Fig. 7B). The correlation is probably weak because the noncarbonate fraction is dominated by detrital and hydrothermal phases that have densities close to the density of the calcium carbonate.

Previous studies have related anomalous sediment physical properties to alteration by hydrothermal circulation. For example, sediments from high heat flow areas in the Galapagos Mounds hydrothermal field showed anomalously high porosity and density gradients (Karato and Becker, 1983), and sediments from high heat flow zones in the Mariana Mounds hydrothermal field had very low water contents and showed evidence of cementation (Leinen and Anderson, 1981; Maris et al., 1985). Core GC 8 in Area III was taken at the location of a heat flow measurement of $753 \mathrm{~mW} / \mathrm{m}^{2}$. Both the corer and the heat flow probe were deployed with a relay transponder, and their locations within the transponder navigation net for Area III are identical within the accuracy of navigation $( \pm 10 \mathrm{~m})$. The core showed no consistent relationship between water content, density, and sedimentological properties like calcium carbonate content (Fig. 7B), but other cores from normal heat flow regions in the same area also showed no consistent relationship between physical and sedimentological properties. Thus, the physical properties of the sediments provide no corroborative evidence for hydrothermal circulation through the sediments in Area III.

\section{Chemistry of Ariadne II Sediments}

Previous studies have shown that central South Pacific surface sediments are an intimate mixture of detrital, biogenic, hydrogenous, and hydrothermal phases (e.g., Boström et al., 1973; Heath and Dymond, 1977; Dymond, 1981; Heath and Dymond, 1981). Leinen and Pi- 


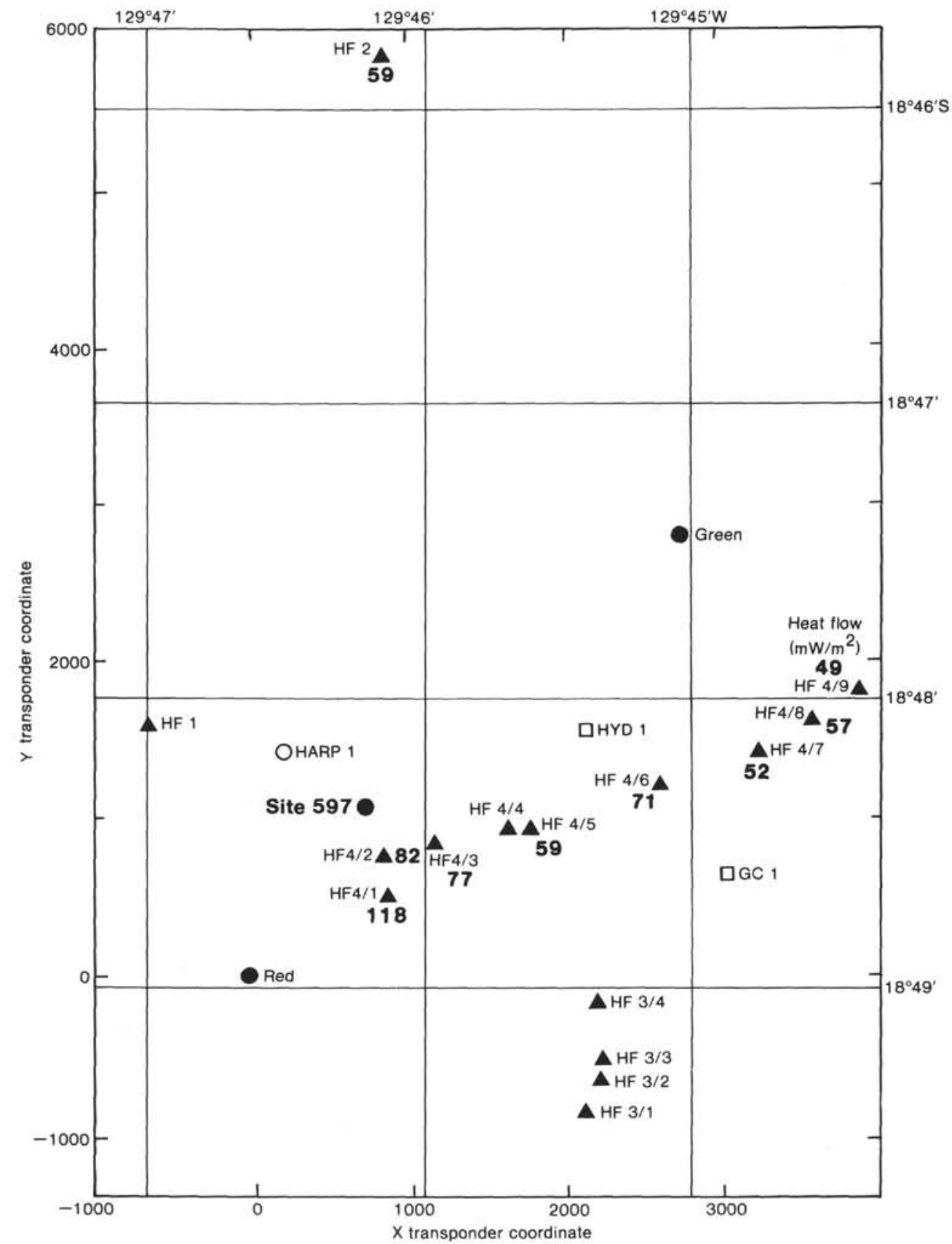

Figure 2. Location of heat flow (HF) and coring stations in Area I surveyed by Ariadne II. Triangles are multipenetration heat flow stations (designations are the heat flow run followed by the measurement number; e.g., 3/4). GC $=$ gravity core location, HARP $=$ pore water harpoon, HYD $=$ hydrocast. Transponder locations are designated by color. Numbers next to stations are heat flow values in $\mathrm{mW} /$ $\mathrm{m}^{2}$. Values along transponder coordinate axes are in meters.

sias (1984) and Leinen (in press) have demonstrated that multivariate factor analysis can be used to determine the number and chemical composition of the sediment endmembers in such sediments. Dymond (1981) and Leinen and Pisias (1984) have also demonstrated that linear programming can be used to optimize the partitioning of the sediment into the end-members indicated by the factor analysis. To analyze the bulk-sediment chemistry, a suite of samples from the Ariadne II cores were subjected to a modified Q-mode factor analysis (Leinen and Pisias, 1984). This analysis indicated that four factors accounted for $97 \%$ of the sums of squares in the data. The factor scores (Table 5) show the relative importance of the variance of each variable in each end-member, and the rotated composition vectors (Table 5) for each of the end-members show the chemical compositions of the end-members.

Both the factor scores and rotated composition vectors suggest that factor 1 is dominated by $\mathrm{Fe}$ - and $\mathrm{Mn}$ oxides. Both $\mathrm{Zn}$ and (to a lesser extent) $\mathrm{Cu}$ are also important in explaining the variance associated with this vector, although the concentrations of these substances 


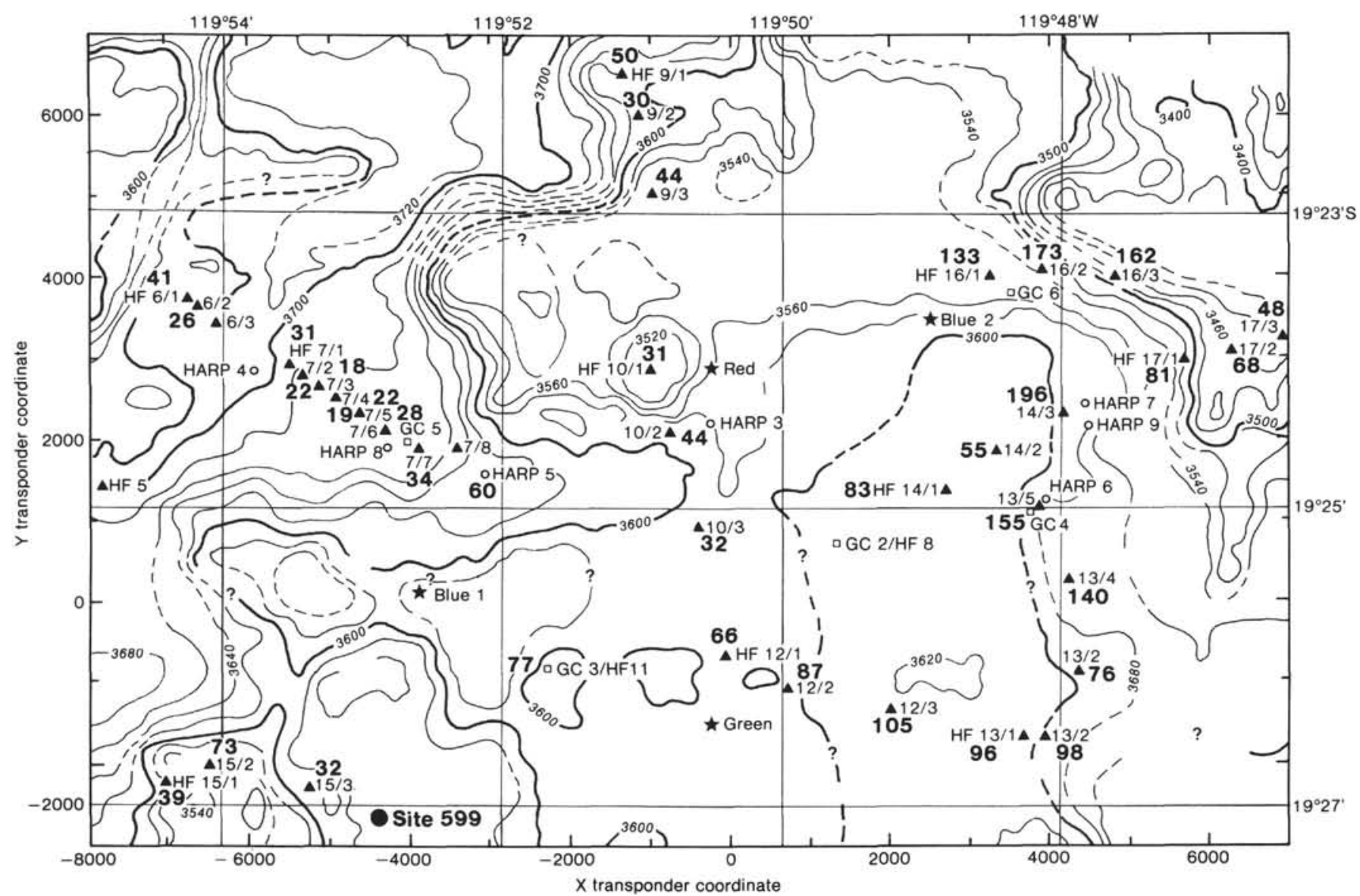

Figure 3. Location of heat flow and coring stations in Area II surveyed by Ariadne II. Contours are based on the Seabeam swath mapping. Coverage was incomplete, and areas between Seabeam swaths are indicated with dashed contours. Contour interval is $20 \mathrm{~m}$. Other details as for Fig. 1 .

are lower than those of $\mathrm{Fe}$ and $\mathrm{Mn}$. The composition vector contains no $\mathrm{SiO}_{2}$ and little $\mathrm{Al}_{2} \mathrm{O}_{3}$, and the variance vector shows an inverse relationship between the transition elements and $\mathrm{SiO}_{2}$ in the factor. Although $\mathrm{SiO}_{2}$ is common in hydrothermal vent fluids (Edmond et al., 1979; von Damm and Edmond, 1982), previous studies show that little of this silica is present in the metalliferous hydrothermal sediments deposited near the East Pacific Rise or in metalliferous hydrothermal sediment transported through the water column and deposited at greater distances from the ridge axis (Heath and Dymond, 1977; Dymond, 1981; Leinen and Pisias, 1984). Thus, these composition and variance associations suggest that the factor represents transported hydrothermal sediment. The concentration of the factor is highest in sediments from Area IV (Table 6), close to the East Pacific Rise. The $\mathrm{Fe} / \mathrm{Mn}$ ratio of the factor composition is 3.8 , however, somewhat larger than that of typical hydrothermal sediment from the East Pacific Rise (Boström et al., 1973; Heath and Dymond, 1977; Dymond, 1981; McMurtry et al., 1981).

Factor 2 is dominated by the variances of $\mathrm{SiO}_{2}, \mathrm{BaO}$, and $\mathrm{MgO}$. In other samples from the southeastern $\mathrm{Pa}$ cific, Dymond (1981) and Leinen and Pisias (1984) found that this element association was characteristic of siliceous biogenic sediment and dissolving siliceous debris. No siliceous microfossils were found in the Ariadne II sediments, however, so if the silica in this factor is biogenic it must have been incorporated into other phases by postdepositional processes. This supposition is reasonable, since previous studies of the diagenesis of hydrothermal sediments in regions of low sedimentation rate (Dymond and Eklund, 1978; Heath and Dymond, 1977) suggest that the dissolving biogenic silica in such sediments contributes silica for the formation of ironrich authigenic smectites. The composition vectors indicate relatively high concentrations of $\mathrm{Fe}_{2} \mathrm{O}_{3}(24 \%)$ and $\mathrm{MnO}_{2}(5 \%)$ in this factor, and the overall composition is similar to authigenic smectites from the North Pacific (Hein et al., 1979). This factor is most important in samples from the upper few centimeters in cores from Areas II and III, and it dominates sediments from Core GC 8, which was taken in the high heat flow zone of Area III. The silica represented by this factor, because of its lack of association with the hydrothermal component in the first factor, is not likely to represent transported hydrothermal material. It may represent Si-rich hydrothermal contributions from ridge flank hydrothermal advection.

Factor 3 is dominated by the variances of $\mathrm{CoO}$ and $\mathrm{Al}_{2} \mathrm{O}_{3}$. In composition it is rich in $\mathrm{Fe}_{2} \mathrm{O}_{3}, \mathrm{Al}_{2} \mathrm{O}_{3}, \mathrm{MgO}$, and $\mathrm{BaO}$. It is generally abundant in the surface samples from all of the areas and depleted in the sediments immediately below the surface. Its highest concentrations are from Area II (Cores GC 2, GC 5, and GC 6). The 


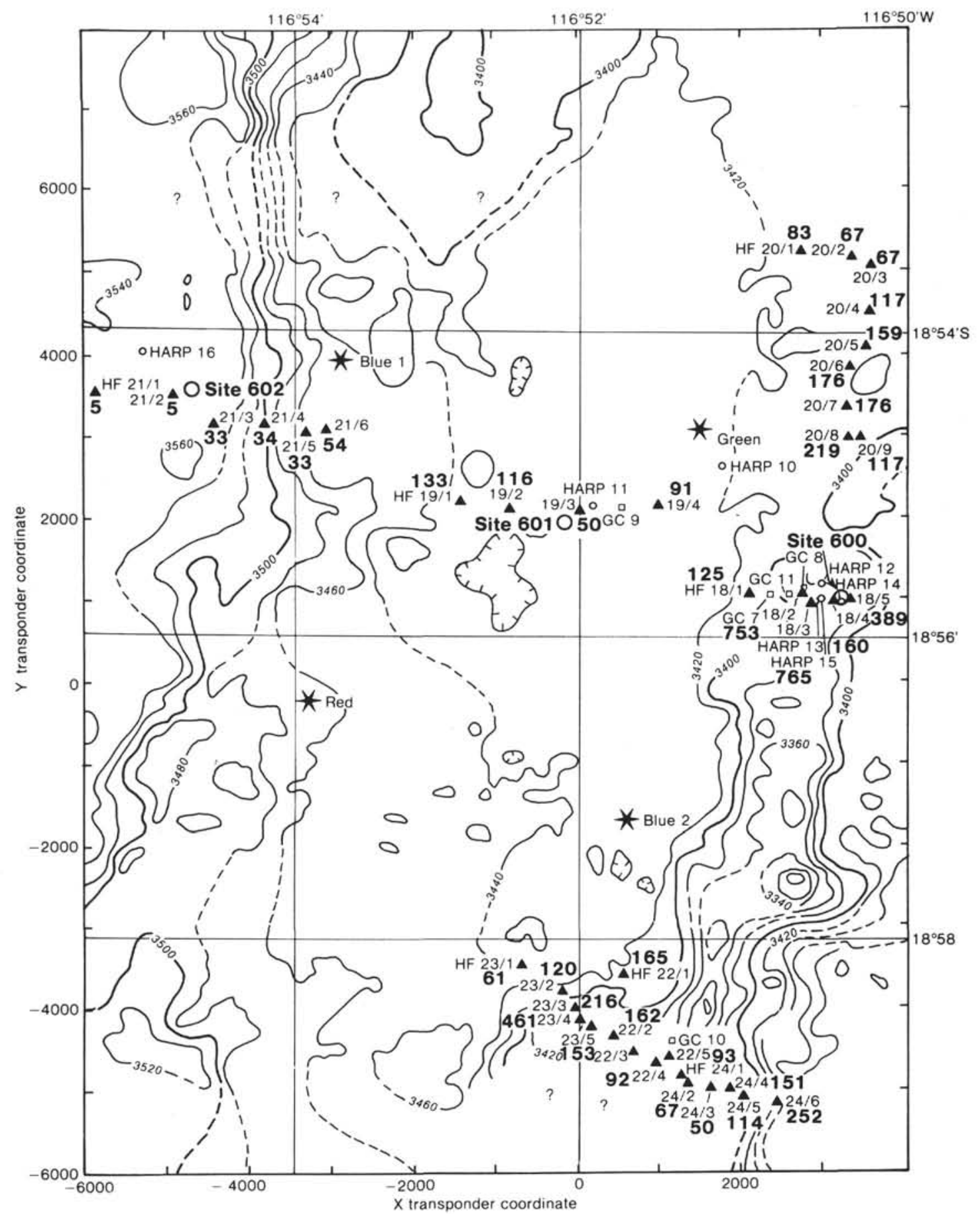

Figure 4. Location of heat flow and coring stations in Area III surveyed by Ariadne II. Details as in Figs. 1 and 2.

high concentration of $\mathrm{BaO}$ suggests that the factor may be related to the dissolution of biogenic test debris (Dymond, 1981; Leinen and Pisias, 1984), although the high concentrations of $\mathrm{CoO}$ are more commonly associated with Mn-rich hydrogenous phases. Lyle $(1981,1983)$ has shown that $\mathrm{Mn}$ and $\mathrm{Fe}$ are concentrated by oxic diagenesis into the surface sediment. Lyle (1981) and Heggie (D. Heggie, pers. comm., 1984) have also shown that Co is concentrated in such phases. The factor may represent a mixture of dissolution and oxic diagenesis phas- es, the variances of which are associated because the phases are most enriched in the same sediments.

Factor 4 explains $4 \%$ of the variance in the total data set and is dominated by the variance of $\mathrm{Al}_{2} \mathrm{O}_{3}$. $\mathrm{Al}$ is always very strongly associated with the detrital phases in deep-sea sediments (Heath and Dymond, 1977; McMurtry et al., 1981; Dymond, 1981; Leinen and Pisias, 1984). The $\mathrm{Si} / \mathrm{Al}$ ratio of the factor is 2.8 , close to that of detritus on the Nazca Plate (Dymond, 1981). Although the vector might represent detritus, the composition vector 


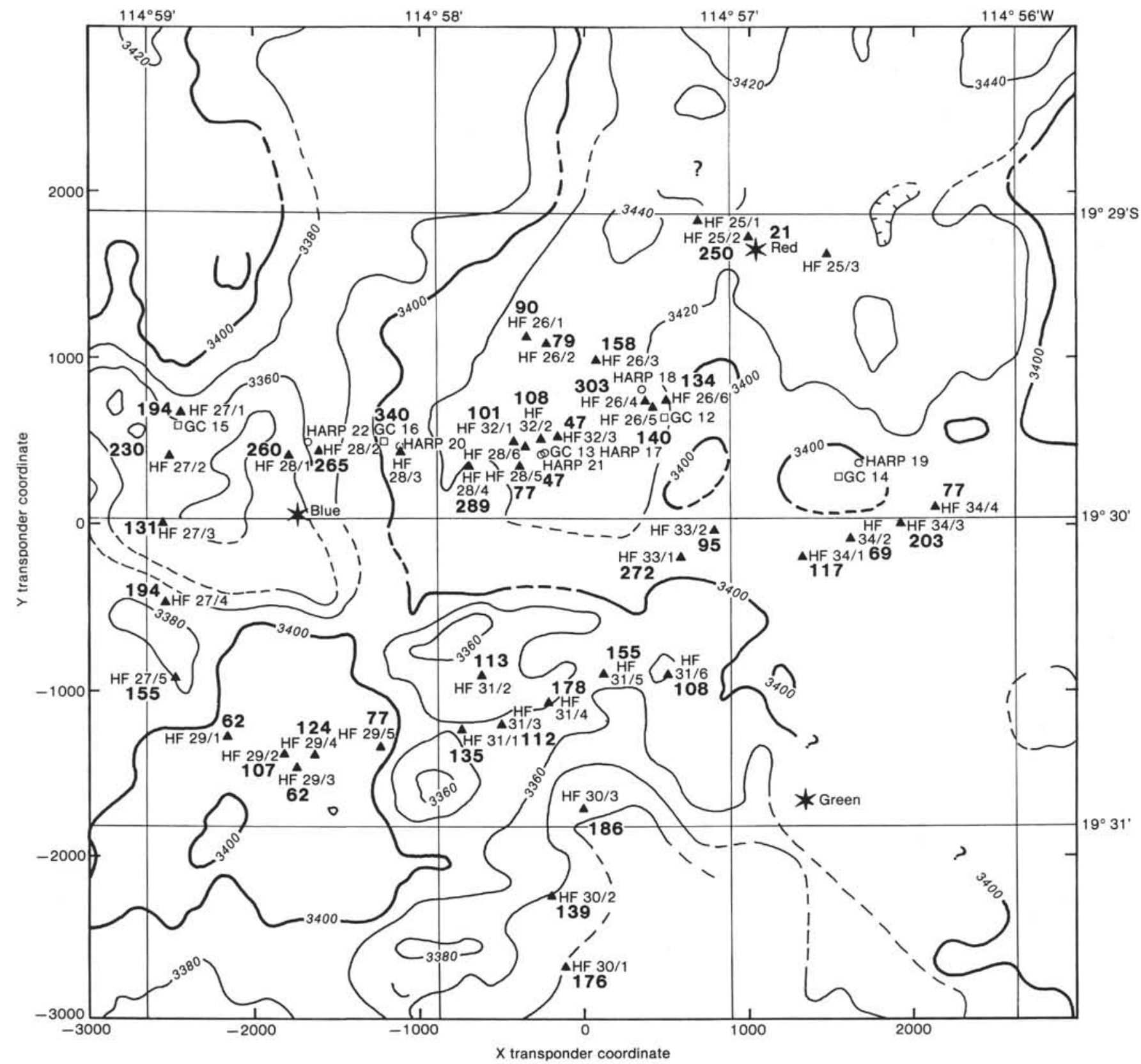

Figure 5. Location of heat flow and coring stations in Area IV surveyed by Ariadne II. Details as in Figs. 1 and 2.

also has high concentrations of $\mathrm{Fe}$ and $\mathrm{Mn}$. Further, the $\mathrm{Fe} / \mathrm{Mn}$ ratio in the composition vector is 3.5 , close to that of hydrothermal sediments from the EPR and similar to that of factor 1 , which we have inferred to be of hydrothermal origin. Factor 4 may therefore include hydrothermal or hydrogenous oxides in addition to detritus. This factor is abundant only in the sediments from Area I, which are farthest from the ridge crest and which are accumulating at the lowest rate (cf. Site 597 summary). Studies of the non-authigenic, crystalline fraction of surface sediments from Site 597 (Bloomstine and Rea, this volume) and chemical leaching experiments (Kastner, this volume) suggest that the surface sediments from Area I have the highest detrital content of any of the sites.
Leinen (in press) has demonstrated that a statistically determined end-member composition can be contaminated by another end-member composition when the variation in the data set is insufficient to separate the two end-members. In order to determine whether the compositions of factors 2 and 4 were not well characterized because all sediments contained abundant hydrothermal material, we partitioned the sediments by using the linear programming technique of Dymond (1981), who studied the surface sediments of the southeastern Pacific in detail. The compositions of the Dymond end-members are presented in Table 7. (Several samples could not be included in this analysis because their $\mathrm{Co}$ and $\mathrm{Ni}$ concentrations were not available.) The fit of Dymond's five-end-member compositional model to the Ariadne II 
Table 4. Biostratigraphy of selected site survey cores. Zonation is that used in Knüttel (this volume).

\begin{tabular}{|c|c|c|c|c|c|}
\hline Core & $\begin{array}{l}\text { Depth } \\
\text { within core } \\
(\mathrm{cm})\end{array}$ & Preservation & Abundance $^{\mathrm{a}}$ & Zone & Age \\
\hline \multicolumn{6}{|l|}{ Area I } \\
\hline GC 1 & $\begin{array}{c}6-7 \\
50-51 \\
101-102 \\
150-151 \\
180-181\end{array}$ & G & $\begin{array}{l}\text { A } \\
\text { B } \\
\text { B } \\
\text { B } \\
\text { B }\end{array}$ & $\begin{array}{c}\mathrm{CN} 14 / 15 \\
? \\
? \\
? \\
?\end{array}$ & Pleistocene \\
\hline \multicolumn{6}{|l|}{ Area II } \\
\hline GC 2 & $\begin{array}{c}2-3 \\
50-51 \\
100-101\end{array}$ & $\begin{array}{l}G \\
G \\
G\end{array}$ & $\begin{array}{l}\mathrm{V} \\
\mathrm{V} \\
\mathrm{V}\end{array}$ & $\begin{array}{l}\text { CN14(?15) } \\
\text { CN14 } \\
\text { CN14 }\end{array}$ & $\begin{array}{l}\text { Pleistocene } \\
\text { Pleistocene } \\
\text { Pleistocene }\end{array}$ \\
\hline GC 5 & $\begin{array}{c}2-3 \\
50-51 \\
72-73\end{array}$ & $\begin{array}{l}G \\
G \\
G\end{array}$ & $\begin{array}{l}\text { v } \\
\text { v } \\
\text { v }\end{array}$ & $\begin{array}{l}\mathrm{CN} 14 / 15 \\
\mathrm{CN} 14(? 15) \\
\mathrm{CN} 14(? 13)\end{array}$ & $\begin{array}{l}\text { Pleistocene } \\
\text { Pleistocene } \\
\text { Pleistocene }\end{array}$ \\
\hline GC 6 & $\begin{array}{c}2-3 \\
50-51 \\
100-101 \\
150-151\end{array}$ & $\begin{array}{l}\mathrm{G} \\
\mathrm{G} \\
\mathrm{M} \\
\mathrm{M}\end{array}$ & $\begin{array}{l}\mathrm{V} \\
\mathrm{V} \\
\mathrm{V} \\
\mathrm{V}\end{array}$ & $\begin{array}{l}\mathrm{CN} 14 / 15 \\
\mathrm{CN} 14(? 15) \\
\mathrm{CN} 14(? 13) \\
\mathrm{CN} 13\end{array}$ & $\begin{array}{l}\text { Pleistocene } \\
\text { Pleistocene } \\
\text { Pleistocene } \\
\text { Pliocene }\end{array}$ \\
\hline \multicolumn{6}{|l|}{ Area III } \\
\hline GC 7 & $\begin{array}{c}6-8 \\
299-300\end{array}$ & $\begin{array}{l}\text { G } \\
\text { G }\end{array}$ & $\begin{array}{l}\mathrm{V} \\
\mathrm{V}\end{array}$ & $\begin{array}{l}\text { CN14(?15) } \\
\text { CN14 }\end{array}$ & $\begin{array}{l}\text { Pleistocene } \\
\text { Pleistocene }\end{array}$ \\
\hline GC 8 & $\begin{array}{c}2-3 \\
150-151 \\
200-201\end{array}$ & $\begin{array}{l}\text { G } \\
\text { G } \\
\text { G }\end{array}$ & $\begin{array}{l}\mathrm{V} \\
\mathrm{V} \\
\mathrm{v}\end{array}$ & $\begin{array}{l}\mathrm{CN} 14(? 15) \\
\mathrm{CN} 14(? 15) \\
\mathrm{CN} 13\end{array}$ & $\begin{array}{l}\text { Pleistocene } \\
\text { Pleistocene } \\
\text { Pliocene }\end{array}$ \\
\hline \multicolumn{6}{|l|}{ Area IV } \\
\hline GC 13 & $\begin{array}{c}2-3 \\
50-51 \\
100-101\end{array}$ & $\begin{array}{l}G \\
G \\
G\end{array}$ & $\begin{array}{l}\text { V } \\
\text { V } \\
\text { V }\end{array}$ & $\begin{array}{l}\mathrm{CN} 14 / 15 \\
\mathrm{CN} 14 / 15 \\
\mathrm{CN} 14(? 15)\end{array}$ & $\begin{array}{l}\text { Pleistocene } \\
\text { Pleistocene } \\
\text { Pleistocene }\end{array}$ \\
\hline GC 16 & $\begin{array}{c}2-3 \\
50-51 \\
100-101 \\
150-151 \\
200-201 \\
250-251 \\
300-301 \\
350-351\end{array}$ & $\begin{array}{l}\mathrm{G} \\
\mathrm{G} \\
\mathrm{G} \\
\mathrm{G} \\
\mathrm{M} \\
\mathrm{M} \\
\mathrm{M} \\
\mathrm{G}\end{array}$ & $\begin{array}{l}\text { V } \\
\text { V } \\
\text { V } \\
\text { V } \\
\text { A } \\
\text { V } \\
\text { A } \\
\text { V }\end{array}$ & $\begin{array}{l}\mathrm{CN} 14(? 15) \\
\mathrm{CN} 14(? 15) \\
\mathrm{CN} 14(? 15) \\
\mathrm{CN} 14 \\
\mathrm{CN} 14 \\
\mathrm{CN} 13 \\
\mathrm{CN} 13 \\
\mathrm{CN} 13\end{array}$ & $\begin{array}{l}\text { Pleistocene } \\
\text { Pleistocene } \\
\text { Pleistocene } \\
\text { Pleistocene } \\
\text { Pleistocene } \\
\text { Pleistocene } \\
\text { Pliocene } \\
\text { Pliocene }\end{array}$ \\
\hline
\end{tabular}

${ }^{\mathrm{a}} \mathrm{A}=$ abundant; $\mathrm{B}=$ barren; $\mathrm{V}=$ very abundant. sediments was very good (coefficient of determination $>98 \%$ for all elements except $\mathrm{Mn}$; Table 8). This partitioning suggests that the noncarbonate sediments in Area I are dominated by detritus and hydrothermal phases, whereas those in Areas II to IV are dominated by hydrothermal phases and phases related to dissolved siliceous biogenic material. Figure 8 shows the accumulation rate of hydrothermal sediment in Core GC 8 estimated by the factor analysis and linear programming techniques. The figure also compares the concentration of hydrothermal sediment estimated by the two techniques. The linear programming technique estimates nearly twice as much hydrothermal material as the factor analysis, but the relationship between the two estimates is linear. We interpret the discrepancy between the estimates as being the result of the incorporation of some of the hydrothermal material into the other factors as discussed above. The linear relationship between the two estimates suggests that either would give a good estimate of the relative importance of hydrothermal material in different samples, however. The hydrothermal end-member in Dymond's model does contain $\mathrm{SiO}_{2}$. It is interesting that the linear programming technique also suggested a significant chemical contribution to the sediments from biogenic silica in addition to the silica associated with hydrothermal sediments, even though no siliceous microfossils were preserved in the sediments.

\section{Accumulation Rates of Elements and Sediment Components}

Bulk-sediment accumulation rates, $r$, were calculated from $r=s p$, where $s$ is the linear sedimentation rate (Table 9) and $p$ is the sediment dry-bulk density. The accumulation rates of individual elements and sediment components (Table 9) are the product of the weight fraction of the element or component and the bulk-sediment accumulation rates.

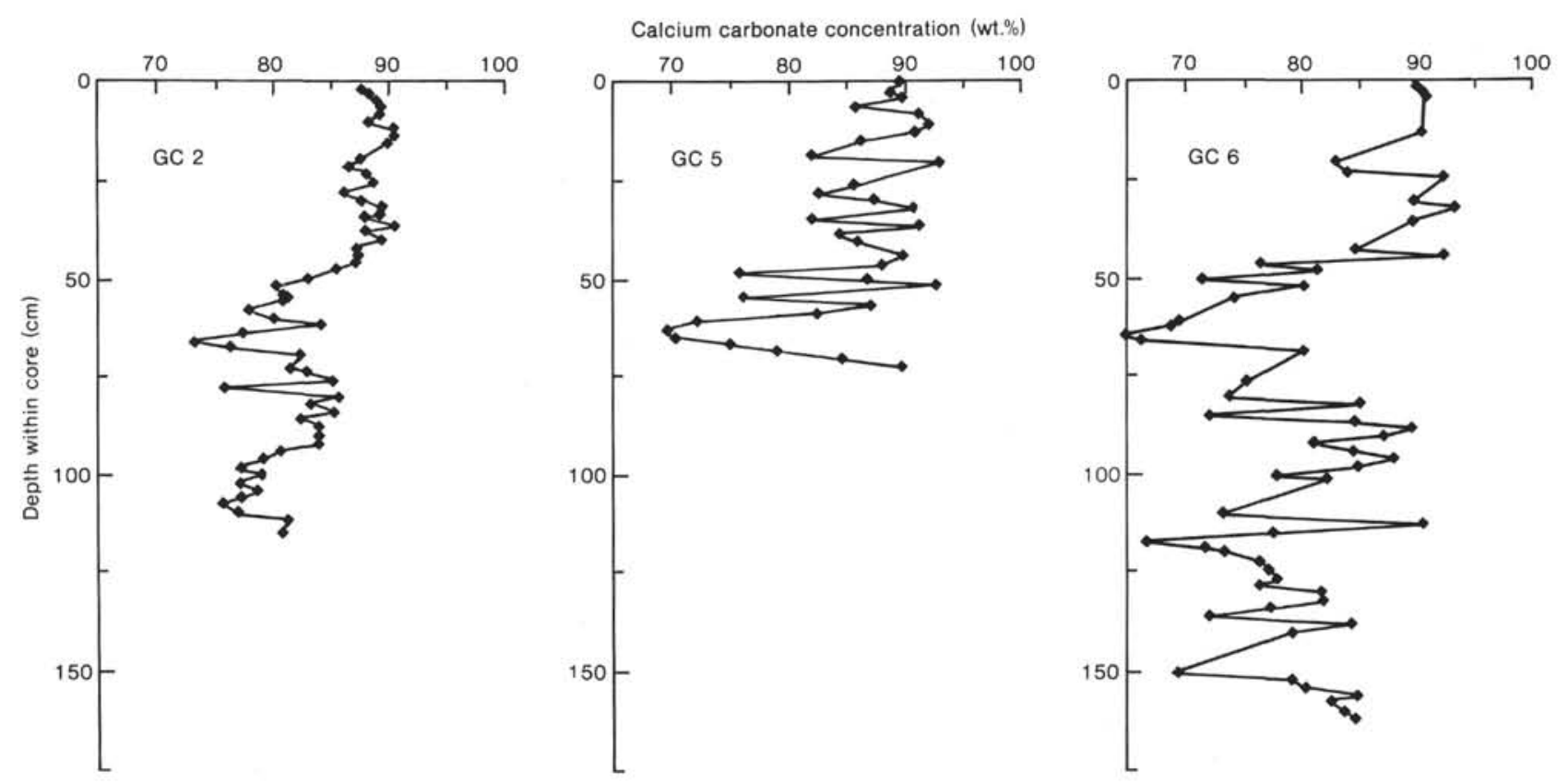

Figure 6. Calcium carbonate contents of gravity cores from Area II. Core locations are shown in Fig. 3. 

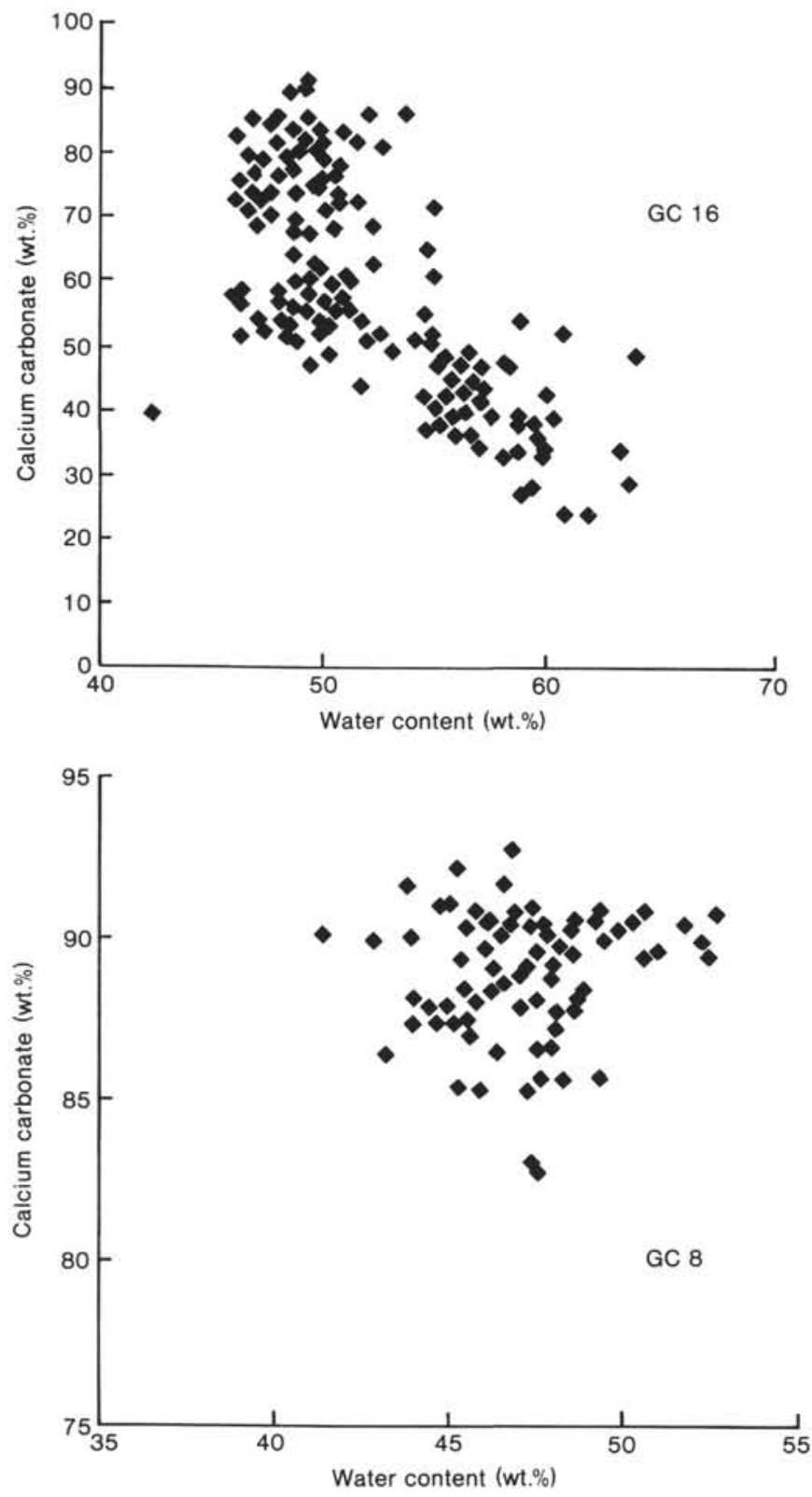

Figure 7. Calcium carbonate concentration versus water content for Cores GC 16 and GC 8.

The individual element and component accumulation rates are highly dependent on the stratigraphy, which is very coarse, and therefore these accumulation rates cannot be determined with great precision. The accumulation rates do, however, convey an accurate picture of overall variations in space and time. For example, the accumulation rates confirm the decrease in Fe concentration and accumulation rate that was observed as part of a trend with age and distance from the EPR at each of the Leg 92 drill sites by Lyle et al. (this volume). The decrease in the accumulation rates of elements associated with hydrothermal phases (e.g., $\mathrm{Fe}, \mathrm{Mn}, \mathrm{Cu}, \mathrm{Zn}$ ) with increasing distance from the ridge crest also corroborates the decrease in the amount of the hydrothermal phase suggested by factor analysis. Figure 9 shows the rate of accumulation of the factor analysis hydrother-
Table 5. Factor scores and rotated composition vectors for Ariadne II sediments (see text).

\begin{tabular}{crrrr}
\hline Variable & Factor 1 & Factor 2 & Factor 3 & Factor 4 \\
\hline Factor scores & & & & \\
& & & & \\
$\mathrm{MgO}$ & 0.419 & 1.183 & 0.424 & -0.957 \\
$\mathrm{Al}_{2} \mathrm{O}_{3}$ & -0.143 & 0.084 & 1.330 & 2.182 \\
$\mathrm{SiO}_{2}$ & -0.701 & 2.462 & -0.012 & 0.472 \\
$\mathrm{MnO}_{2}$ & 1.418 & 0.153 & -0.102 & 0.492 \\
$\mathrm{Fe}_{2} \mathrm{O}_{3}$ & 1.186 & 0.287 & 0.136 & 0.186 \\
$\mathrm{CoO}$ & 0.446 & -0.740 & 2.446 & -0.969 \\
$\mathrm{NiO}$ & 0.523 & 0.307 & 0.582 & 1.210 \\
$\mathrm{CuO}$ & 0.881 & 0.303 & 0.466 & 0.204 \\
$\mathrm{ZnO}$ & 2.155 & 0.256 & -0.856 & -0.102 \\
$\mathrm{BaO}$ & 0.028 & 1.274 & 0.865 & -1.151
\end{tabular}

End-member compositions (rotated factor vectors)

\begin{tabular}{lrrrr}
$\mathrm{MgO}$ & 6.03 & 6.77 & 7.93 & 0.88 \\
$\mathrm{Al}_{2} \mathrm{O}_{3}$ & 2.39 & 2.24 & 10.80 & 11.27 \\
$\mathrm{SiO}_{2}$ & 0.00 & 58.98 & 27.17 & 36.01 \\
$\mathrm{MnO}_{2}$ & 20.10 & 5.34 & 8.13 & 12.27 \\
$\mathrm{Fe}_{2} \mathrm{O}_{3}$ & 69.52 & 24.12 & 41.90 & 39.03 \\
$\mathrm{CoO}$ & 0.03 & 0.00 & 0.10 & 0.00 \\
$\mathrm{NiO}$ & 0.13 & 0.07 & 0.18 & 0.20 \\
$\mathrm{CuO}$ & 0.35 & 0.15 & 0.34 & 0.24 \\
$\mathrm{ZnO}$ & 0.19 & 0.04 & 0.00 & 0.06 \\
$\mathrm{BaO}$ & 1.27 & 2.29 & 3.46 & 0.04 \\
\hline
\end{tabular}

Table 6. Concentration (wt.\%) of factor analysis end-members in selected site survey core samples.

\begin{tabular}{|c|c|c|c|c|c|}
\hline Core & $\begin{array}{l}\text { Depth } \\
\text { within core } \\
(\mathrm{cm})\end{array}$ & $\begin{array}{c}\text { Factor } 1 \\
\text { (hydrothermal) }\end{array}$ & $\begin{array}{c}\text { Factor 2 } \\
\text { (biogenic?) }\end{array}$ & $\begin{array}{c}\begin{array}{c}\text { Factor } 3 \\
\text { (dissolution) }\end{array}\end{array}$ & $\begin{array}{l}\text { Factor } 4 \\
\text { (detritus) }\end{array}$ \\
\hline \multicolumn{6}{|l|}{ Area I } \\
\hline GC 1 & $0-1$ & 0 & 15 & 6 & 80 \\
\hline \multicolumn{6}{|l|}{ Area II } \\
\hline GC 2 & $\begin{array}{c}1-2 \\
6-7 \\
28-29 \\
66-67 \\
80-81 \\
108-109\end{array}$ & $\begin{array}{r}25 \\
0 \\
40 \\
30 \\
36 \\
30\end{array}$ & $\begin{array}{r}63 \\
86 \\
26 \\
10 \\
14 \\
5\end{array}$ & $\begin{array}{r}12 \\
2 \\
23 \\
42 \\
36 \\
47\end{array}$ & $\begin{array}{r}0 \\
12 \\
11 \\
18 \\
14 \\
18\end{array}$ \\
\hline GC 5 & $\begin{array}{c}0-2 \\
10-11 \\
34-35 \\
62-63\end{array}$ & $\begin{array}{r}28 \\
3 \\
41 \\
27\end{array}$ & $\begin{array}{l}31 \\
78 \\
13 \\
15\end{array}$ & $\begin{array}{r}41 \\
0 \\
46 \\
27\end{array}$ & $\begin{array}{r}0 \\
19 \\
0 \\
30\end{array}$ \\
\hline GC 6 & $\begin{array}{c}0-2 \\
10-11 \\
30-31 \\
64-65 \\
82-83 \\
116-117\end{array}$ & $\begin{array}{r}24 \\
13 \\
37 \\
0 \\
42 \\
30\end{array}$ & $\begin{array}{r}22 \\
76 \\
41 \\
0 \\
18 \\
10\end{array}$ & $\begin{array}{r}38 \\
0 \\
22 \\
61 \\
34 \\
43\end{array}$ & $\begin{array}{r}17 \\
11 \\
0 \\
39 \\
6 \\
6 \\
17\end{array}$ \\
\hline
\end{tabular}

Area III

$$
\text { GC } 8
$$

$0-1$
$6-7$
$48-49$
$10-107$
$138-139$
$174-175$
$202-203$

38
0
10
20
39
11
27

35
93
84
74
40
75
70

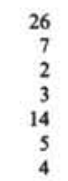

Area IV

\begin{tabular}{lccccr} 
GC 13 & $0-1$ & 66 & 26 & 9 & 0 \\
GC 16 & $1-2$ & 63 & 26 & 11 & 0 \\
& $142-143$ & 71 & 21 & 0 & 7 \\
& $220-221$ & 78 & 15 & 0 & 7 \\
& $372-373$ & 64 & 12 & 0 & 25 \\
\hline
\end{tabular}


Table 7. Linear programming end-members for Ariadne II sediments (Dymond, 1981).

\begin{tabular}{lcrcrr}
\hline Variable & Hydrothermal & Biogenic & Hydrogenous & Dissolution & Detritus \\
\hline $\mathrm{Al}_{2} \mathrm{O}_{3}$ & 0.48 & 0.02 & 3.43 & 34.88 & 20.25 \\
$\mathrm{SiO}_{2}$ & 11.88 & 99.60 & 10.38 & 0.00 & 68.80 \\
$\mathrm{MnO}_{2}$ & 11.02 & 0.00 & 57.48 & 4.08 & 0.03 \\
$\mathrm{Fe}_{2} \mathrm{O}_{3}$ & 67.46 & 0.07 & 26.01 & 18.47 & 10.73 \\
$\mathrm{NiO}$ & 0.05 & 0.00 & 1.52 & 0.30 & 0.02 \\
$\mathrm{CuO}$ & 0.22 & 0.00 & 0.76 & 0.74 & 0.02 \\
$\mathrm{ZnO}$ & 0.10 & 0.05 & 0.15 & 0.18 & 0.01 \\
$\mathrm{BaO}$ & 0.24 & 0.10 & 0.27 & 41.34 & 0.14 \\
\hline
\end{tabular}

mal component in sediments from the various cores. The factor analysis estimates were used even though they probably underestimate the total hydrothermal accumulation rate because more samples were included in the factor analysis.

The accumulation rates in Table 9 suggest that the sedimentation rate used for GC 8 (Area III) may be too high. The $\mathrm{Al}$ accumulation rate, for example, which should be almost entirely detrital, is about double that for Core GC 16, which is much closer to continental sources. The $\mathrm{Si}$ accumulation rates are also higher than those at other sites. (There was no evidence of basalt detritus in the upper portion of Site 600 or in the gravity cores from Area III to suggest that the $\mathrm{Al}$ accumulation rate reflects basaltic input.) Since the core site is on the flank of the abyssal-hill ridge, the accumulation rates may reflect some redeposited sediment. Even if the $\mathrm{Al}$ accumulation rate were reduced to the same rate as at the other sites, however, the $\mathrm{Si}$ accumulation rates at GC 8 would be significantly greater than those at other sites. There are no siliceous microfossils in the core and no other evidence of greater biological influence than at the other sites. Bender et al. (in press) have suggested that the advection of silica-rich pore water takes place at the site of Core GC 8. It is possible that such advection has resulted in the precipitation of nonbiogenic silica in the sediments at GC 8 .

\section{CONCLUSIONS}

The site survey cores indicate that the sediments along the transect are dominantly nannofossil ooze and brown clays and that the deposition of these sediments on the plateaus of the Leg 92 drill sites has been quite uniform since at least the late Pliocene. Chemical analyses and

Table 8. Concentration (wt.\%) of linear programming end-members in selected site survey core samples.

\begin{tabular}{|c|c|c|c|c|c|c|}
\hline Core & $\begin{array}{l}\text { Depth } \\
\text { within core } \\
(\mathrm{cm})\end{array}$ & $\begin{array}{l}\text { End-member } 1 \\
\text { (hydrothermal) }\end{array}$ & $\begin{array}{c}\text { End-member } 2 \\
\text { (biogenic) }\end{array}$ & $\begin{array}{c}\text { End-member } 3 \\
\text { (dissolution) }\end{array}$ & $\begin{array}{c}\text { End-member } 4 \\
\text { (detritus) }\end{array}$ & $\begin{array}{l}\text { End-member } 5 \\
\text { (hydrogenous) }\end{array}$ \\
\hline \multicolumn{7}{|l|}{ Area I } \\
\hline GC 1 & $0-1$ & 62.5 & 0.0 & 2.4 & 34.4 & 0.7 \\
\hline \multicolumn{7}{|l|}{ Area II } \\
\hline GC 2 & $\begin{array}{c}1-2 \\
6-7 \\
28-29 \\
66-67 \\
80-81 \\
108-109\end{array}$ & $\begin{array}{l}59.2 \\
38.8\end{array}$ & $\begin{array}{l}33.7 \\
55.8\end{array}$ & $\begin{array}{l}5.7 \\
2.8\end{array}$ & $\begin{array}{l}1.3 \\
2.4\end{array}$ & $\begin{array}{l}0.2 \\
0.1\end{array}$ \\
\hline GC 5 & $\begin{array}{c}0-2 \\
10-11 \\
34-35 \\
62-63\end{array}$ & $\begin{array}{l}76.1 \\
45.5\end{array}$ & $\begin{array}{l}10.5 \\
47.4\end{array}$ & $\begin{array}{l}6.6 \\
3.7\end{array}$ & $\begin{array}{l}6.7 \\
3.4\end{array}$ & $\begin{array}{l}0.1 \\
0.1\end{array}$ \\
\hline GC 6 & $\begin{array}{c}0-2 \\
10-11 \\
30-31 \\
64-65 \\
82-83 \\
116-117\end{array}$ & $\begin{array}{l}79.8 \\
51.1\end{array}$ & $\begin{array}{r}6.4 \\
41.7\end{array}$ & $\begin{array}{l}8.4 \\
5.1\end{array}$ & $\begin{array}{l}5.4 \\
1.9\end{array}$ & $\begin{array}{l}0.0 \\
0.2\end{array}$ \\
\hline \multicolumn{7}{|l|}{ Area III } \\
\hline GC 8 & $\begin{array}{c}0-1 \\
6-7 \\
48-49 \\
106-107 \\
138-139 \\
174-175 \\
202-203\end{array}$ & $\begin{array}{l}80.3 \\
35.9 \\
45.9 \\
55.3 \\
80.1 \\
48.3 \\
62.1\end{array}$ & $\begin{array}{l}11.1 \\
60.8 \\
49.9 \\
39.4 \\
12.0 \\
45.9 \\
31.2\end{array}$ & $\begin{array}{l}6.0 \\
3.4 \\
3.4 \\
4.5 \\
5.2 \\
4.1 \\
6.7\end{array}$ & $\begin{array}{l}2.5 \\
0.0 \\
0.9 \\
0.7 \\
2.5 \\
1.6 \\
0.0\end{array}$ & $\begin{array}{l}0.2 \\
0.0 \\
0.1 \\
0.1 \\
0.2 \\
0.1 \\
0.0\end{array}$ \\
\hline \multicolumn{7}{|l|}{ Area IV } \\
\hline GC 13 & $0-1$ & 93.3 & 3.5 & 2.4 & 0.8 & 0.1 \\
\hline GC 16 & $\begin{array}{c}1-2 \\
142-143 \\
220-221 \\
372-373\end{array}$ & $\begin{array}{l}93.1 \\
98.5 \\
99.6 \\
98.7\end{array}$ & $\begin{array}{l}3.5 \\
0.0 \\
0.0 \\
0.0\end{array}$ & $\begin{array}{l}2.4 \\
1.3 \\
0.4 \\
0.0\end{array}$ & $\begin{array}{l}0.9 \\
0.0 \\
0.0 \\
1.3\end{array}$ & $\begin{array}{l}0.1 \\
0.0 \\
0.0 \\
0.0\end{array}$ \\
\hline
\end{tabular}




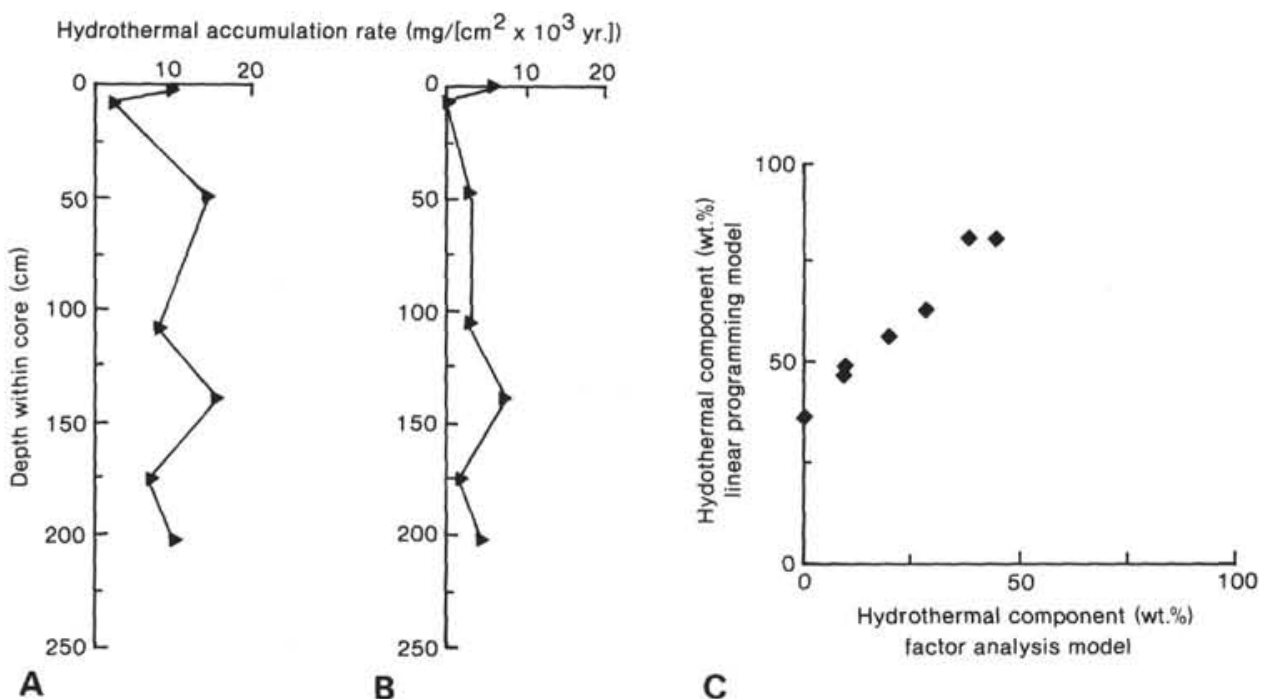

Figure 8. Comparison of the rate of accumulation of hydrothermal sediment in Core GC 8 estimated by linear programming (A) and factor analysis (B); and comparison of the concentration of hydrothermal sediment estimated by the two techniques (C).

Table 9. Element accumulation rates for selected site survey cores.

\begin{tabular}{|c|c|c|c|c|c|c|c|c|c|c|c|c|c|c|}
\hline \multirow[b]{2}{*}{ Core } & \multirow{2}{*}{$\begin{array}{l}\text { Depth } \\
\text { within core } \\
\text { (cm) }\end{array}$} & \multirow[b]{2}{*}{$\begin{array}{c}\text { Age } \\
\left(\times 10^{3} \text { yr. }\right)\end{array}$} & \multicolumn{7}{|c|}{ Accumulation rate $\left(\mathrm{mg} /\left[\mathrm{cm}^{2} \times 10^{3} \mathrm{yr}.\right]\right)$} & \multicolumn{5}{|c|}{$\begin{array}{c}\text { Accumulation rate } \\
\left(\left[\mathrm{mg} /\left\{\mathrm{cm}^{2} \times 10^{3} \mathrm{yr}\right\}\right] \times 1000\right)\end{array}$} \\
\hline & & & $\begin{array}{c}\text { Bulk } \\
\text { sediment }\end{array}$ & $\mathrm{CaCO}_{3}$ & $\mathrm{Mg}$ & Al & $\mathrm{Si}$ & Mn & $\mathrm{Fe}$ & Co & $\mathrm{Ni}$ & $\mathrm{Cu}$ & $\mathrm{Zn}$ & $\mathrm{Ba}$ \\
\hline
\end{tabular}

Area I

GC $1 \quad 0-1$

Area II

GC 2

$\begin{array}{cr}1-2 & 38 \\ 6-7 & 163 \\ 28-29 & 713 \\ 66-67 & 1663 \\ 80-81 & 1770 \\ 108-109 & 1986\end{array}$

GC 5

0-2 25

10-11 263

34-35 863

62-63 1563

GC 6

$\begin{array}{rr}0-2 & 25 \\ 10-11 & 263 \\ 30-31 & 763 \\ 64-65 & 1613 \\ 82-83 & 1751\end{array}$

25
263
763
1613
1751
2013

30
33
32
27
109
90

$\begin{array}{ll}30 & 27 \\ 33 & 30 \\ 27 & 28 \\ 09 & 92 \\ 90 & 70\end{array}$

$\begin{array}{rrrllllrrrr}27 & 0.08 & 0.03 & 0.26 & 0.08 & 0.36 & 2 & 17 & 30 & 9 & 342 \\ 30 & 0.08 & 0.04 & 0.59 & 0.08 & 0.37 & 1 & 13 & 25 & 6 & 275 \\ 28 & 0.08 & 0.06 & 0.21 & 0.15 & 0.68 & & & 50 & 16 & 406 \\ 21 & 0.11 & 0.16 & 0.55 & 0.30 & 1.30 & & & 97 & 27 & 773 \\ 92 & 0.31 & 0.27 & 1.03 & 0.59 & 2.76 & & & 202 & 63 & 1490 \\ 70 & 0.36 & 0.56 & 1.83 & 0.92 & 4.26 & & & 327 & 91 & 2456 \\ & & & & & & & & & & \\ 24 & 0.07 & 0.05 & 0.18 & 0.08 & 0.38 & 6 & 11 & 29 & 9 & 314 \\ 27 & 0.06 & 0.04 & 0.45 & 0.09 & 0.36 & 0 & 15 & 28 & 7 & 284 \\ 26 & 0.08 & 0.08 & 0.29 & 0.17 & 0.73 & & & 54 & 19 & 466 \\ 21 & 0.14 & 0.23 & 0.70 & 0.40 & 1.74 & & & 133 & 35 & 954 \\ & & & & & & & & & & \\ 23 & 0.07 & 0.03 & 0.11 & 0.06 & 0.29 & 6 & 6 & 23 & 7 & 292 \\ 29 & 0.08 & 0.03 & 0.36 & 0.09 & 0.37 & 0 & 18 & 27 & 8 & 353 \\ 31 & 0.08 & 0.05 & 0.24 & 0.13 & 0.56 & & & 42 & 14 & 456 \\ 29 & 0.11 & 0.13 & 0.41 & 0.25 & 1.10 & & & 82 & 23 & 650 \\ 110 & 0.38 & 0.42 & 1.44 & 0.79 & 3.45 & & & 270 & 113 & 2341 \\ 81 & 0.35 & 0.52 & 1.60 & 0.86 & 4.10 & & & 320 & 81 & 2354\end{array}$

Area III

GC 8

$\begin{array}{crr}0-1 & 2 & 145 \\ 6-7 & 28 & 172 \\ 48-49 & 211 & 187 \\ 106-107 & 463 & 181 \\ 138-139 & 602 & 170 \\ 174-175 & 759 & 166 \\ 202-203 & 880 & 201\end{array}$

$\begin{array}{rrrrrrrrrrr}133 & 0.35 & 0.12 & 0.57 & 0.33 & 1.66 & 19 & 51 & 109 & 45 & 1246 \\ 166 & 0.40 & 0.10 & 3.24 & 0.34 & 1.83 & 10 & 52 & 110 & 22 & 1804 \\ 174 & 0.37 & 0.19 & 3.48 & 0.60 & 2.88 & 9 & 67 & 187 & 64 & 2210 \\ 168 & 0.44 & 0.16 & 2.30 & 0.60 & 2.78 & 7 & 91 & 185 & 62 & 2290 \\ 150 & 0.44 & 0.25 & 1.36 & 0.88 & 3.84 & 20 & 131 & 250 & 85 & 2538 \\ 151 & 0.40 & 0.25 & 3.27 & 0.66 & 2.98 & 10 & 104 & 206 & 66 & 2574 \\ 184 & 0.42 & 0.14 & 1.57 & 0.58 & 2.57 & 4 & 52 & 173 & 62 & 2793\end{array}$

Area IV

\begin{tabular}{rrrrrrrrrrrrrrr} 
GC 13 & $0-1$ & 3 & 126 & 107 & 0.39 & 0.13 & 0.83 & 1.02 & 4.36 & 23 & 73 & 223 & 94 & 1306 \\
& & & & & & & & & & \\
GC 16 & $1-2$ & 10 & 61 & 52 & 0.19 & 0.06 & 0.37 & 0.45 & 1.95 & 11 & 37 & 102 & 40 & 597 \\
& $142-143$ & 950 & 113 & 92 & 0.36 & 0.07 & 0.52 & 1.38 & 5.10 & 9 & 141 & 268 & 110 & 930 \\
& $220-221$ & 1470 & 130 & 104 & 0.39 & 0.08 & 0.87 & 1.49 & 5.62 & 0 & 0 & 296 & 118 & 1787 \\
& $372-373$ & 2483 & 68 & 42 & 0.38 & 0.06 & 0.70 & 0.28 & 8.44 & 20 & 140 & 387 & 149 & 791 \\
\hline
\end{tabular}




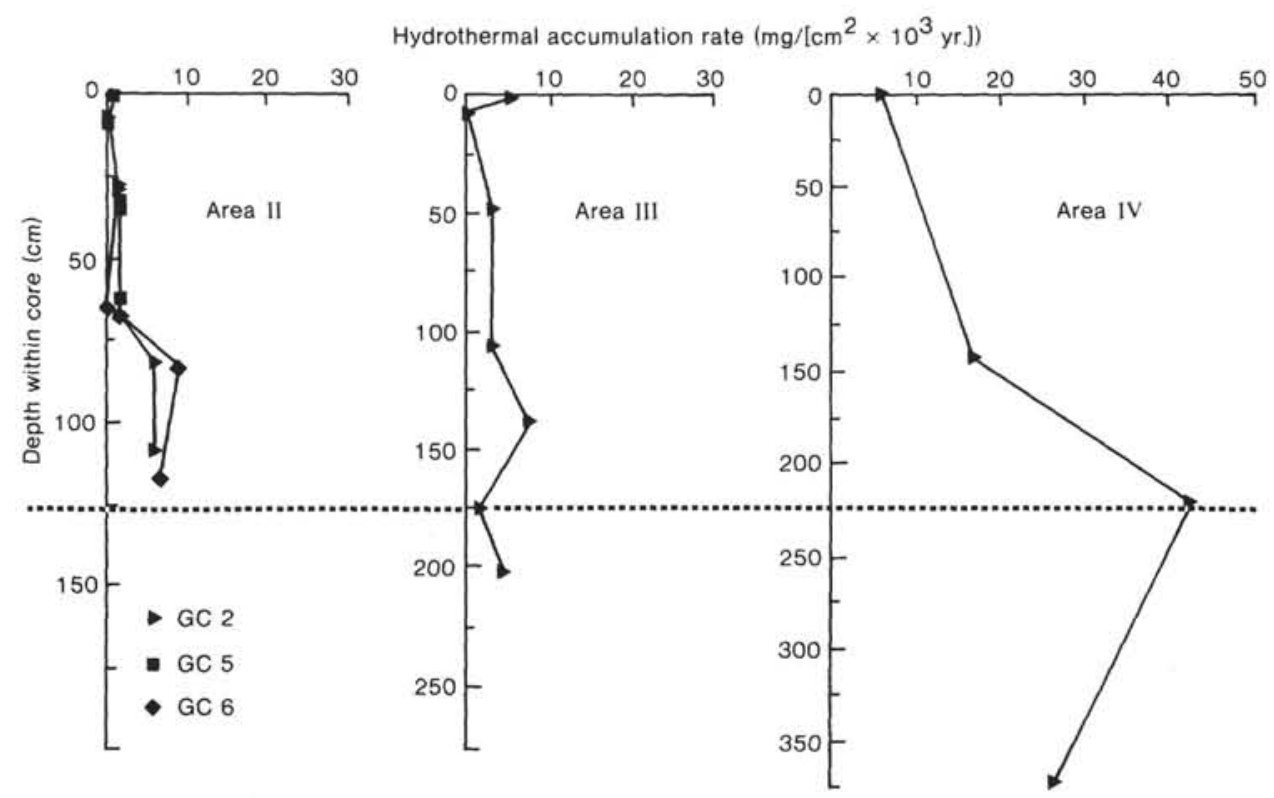

Figure 9. Accumulation rate of hydrothermal sediment in cores from Areas II to IV estimated by factor analysis partitioning. Dotted line shows estimated depth of Pleistocene/Pliocene boundary from nannofossil biostratigraphy.

partitioning studies show that the carbonate-free sediment fraction has at least four end-members: ridge crest hydrothermal sediment transported to the sites through the water column, authigenic and diagenetic sediment phases, biogenic debris, and terrigenous detritus. The partitioning models indicate that the hydrothermal sediment fraction is similar in composition to ridge crest hydrothermal sediment but that it contains far less silica than vent fluids and near-axis precipitates. The authigenic and diagenetic phases are dominated by iron- and manganese-oxide phases (primarily micronodules) and by refractory components left after the dissolution and decomposition of biogenic material. Although none of the cores contained siliceous microfossils, all of the cores had a silica-rich component, which we have interpreted as a geochemical signal from dissolved siliceous biogenic debris because of its lack of association with the ironand manganese-rich amorphous hydrothermal material in the sediments. The terrigenous sediment is similar in composition to the andesitic detritus accumulating in the southeastern Pacific. The noncarbonate fraction shows increasing influence of terrigenous sedimentation and decreasing influence of transported hydrothermal phases with increasing distance from the ridge crest.

Although there was pore water and heat flow evidence of off-axis hydrothermal activity at one of the core sites, the sediments from that site are not unusual in lithology or physical properties. The bulk-sediment chemistry and the chemistry of the hydrothermal component are not anomalous by comparison with the other cores from the area. The sediment does, however, show the slight enrichment in $\mathrm{Si}$ and $\mathrm{Fe}$ characteristic of sediments affected by low-temperature off-axis hydrothermal activity.

\section{ACKNOWLEDGMENTS}

We would like to thank the captain and crew of the Thomas Washington and Mr. Robert Wilson for their assistance in coring and their continued efforts to make coring possible in spite of winch, wire, and corer failures. We would also like to thank Tammy Walsh for her assistance at sea and in sampling. Steve Knüttel graciously added several of our samples to his workload for Leg 92 nannofossil biostratigraphy. This work was supported by JOI, Inc. Contract \#47-81.

\section{REFERENCES}

Bender, M. L., Hudson, A., Graham, D. W., Barnes, R. O., Leinen, M., and Kahn, D., in press. Diagenesis and convection reflected in pore water chemistry on the western flank of the East Pacific Rise, 20 degrees South. Earth Planet. Sci. Lett.

Berger, W. H., 1973. Deep-sea carbonates: Pleistocene dissolution cycles. J. Foraminiferal Res., 3:187-195.

Bernas, B., 1968. A new method for decomposition and comprehensive analysis of silicates by atomic absorption spectrometry. Anal. Chem., 40:1682-1686.

Boström, K., 1974. The origin and fate of ferromanganoan active ridge sediments. Stockholm Contrib. Geol., 27:149-243.

Boström, K., Kraemer, T., and Gartner, S., 1973. Provenance and accumulation rates of opaline silica, $\mathrm{Al}, \mathrm{Ti}, \mathrm{Fe}, \mathrm{Mn}, \mathrm{Cu}, \mathrm{Ni}$ and $\mathrm{Co}$ in Pacific pelagic sediments. Chem. Geol., 11:123-148.

Broecker, W. S., and Broecker, S., 1974. Carbonate dissolution on the western flank of the East Pacific Rise. In Hay, W. W. (Ed.), Studies in Paleoceanography. Spec. Publ. Soc. Econ. Paleontol. Mineral., 20:44-57.

Corliss, J. B., Lyle, M., Dymond, J., and Crane, K., 1978. The chemistry of hydrothermal sediment mound deposits near the Galapagos Rift. Earth Planet. Sci. Lett., 40:1-12.

Dunn, D. A., 1980. Revised techniques for quantitative calcium carbonate analysis using the "Karbonat-Bombe" and comparisons to other quantitative carbonate analysis methods. J. Sediment. Petrol., 50:631-637.

Dymond, J., 1981. Geochemistry of Nazca Plate surface sediments: an evaluation of hydrothermal, biogenic, detrital, and hydrogenous sources. In Kulm, L. D., Dymond, J., Dasch, J., and Hussong, D. (Eds.), Nazca Plate: Crustal Formation and Andean Convergence. Mem. Geol. Soc. Am., 154:133-174.

Dymond, J., and Eklund, W., 1978. A microprobe study of metalliferous sediment components. Earth Planet. Sci. Lett., 40:243-251.

Dymond, J., and Veeh, H. H., 1975. Metal accumulation rates in the southeast Pacific and the origin of metalliferous sediments. Earth Planet. Sci. Lett., 28:13-22.

Edmond, J. M., Measures, C., McDuff, R. E., Chan, L. H., Collier, R., Grant, B., Gordon, L. I., and Corliss, J. B., 1979. Ridge crest hydrothermal activity and the balances of the major and minor el- 
ements in the ocean: the Galapagos data. Earth Planet. Sci. Lett., 46:1-18.

Heath, G. R., and Dymond, J., 1977. Genesis and transformation of metalliferous sediments from the East Pacific Rise, Bauer Deep and Central Basin, Northwest Nazca Plate. Geol. Soc. Am. Bull., 88:723-733.

1981. Metalliferous sediment deposition in time and space: East Pacific Rise and Bauer Basin, northern Nazca Plate. In Kulm, L. D., Dymond, J., Dasch, J., and Hussong, D. (Eds.), Nazca Plate: Crustal Formation and Andean Convergence. Mem. Geol. Soc. Am., 154:175-198.

Hein, J., Yeh, H., and Alexander, E., 1979. Origin of iron-rich montmorillonite from the manganese nodule belt of the North equatorial Pacific. Clays Clay Miner., 27:185-194.

Hobart, M., Abbott, D. H., Anderson, R. N., and Lonsdale, P. F., 1982. Detailed geothermal surveys on the East Pacific Rise at $19^{\circ} \mathrm{S}$. EOS, Trans. Am. Geophys. Union, 63:1103.

Karato, S., and Becker, K., 1983. Porosity and hydraulic properties of sediments from the Galapagos Spreading Center and their relation to hydrothermal circulation in the oceanic crust. J. Geophys. Res., 88:1009-1017.

Leinen, M., in press. The origin of paleochemical signatures in north Pacific pelagic clays: partitioning experiments. Geochim. Cosmochim. Acta.

Leinen, M., and Anderson, R. N., 1981. Hydrothermal sediment from the Mariana Trough. EOS, Trans. Am. Geophys. Union, 62:914.

Leinen, M., and Pisias, N. G., 1984. An objective technique for determining end-member compositions and for partitioning sediments according to their sources. Geochim. Cosmochim. Acta, 48:47-62.
Lyle, M., 1981. Formation and growth of ferromanganese oxides on the Nazca Plate. In Kulm, L. D., Dymond, J., Dasch, E. J., and Hussong, D. (Eds.), Nazca Plate: Crustal Formation and Andean Convergence. Mem. Geol. Soc. Am., 154:269-294.

1983. The significance of the brown-green color change in surface sediments from the Pacific Ocean. Limnol. Oceanogr., 28: 1026-1033.

Lyle, M. W., and Dymond, J., 1976. Metal accumulation rates in southeast Pacific-errors introduced from assumed bulk densities. Earth Planet. Sci. Lett., 30:164-168.

McMurtry, G. M., Veeh, H. H., and Moser, C., 1981. Sediment accumulation rate patterns on the northwest Nazca Plate. In Kulm, L. D., Dymond, J., Dasch, E. J., and Hussong, D. (Eds.), Nazca Plate: Crustal Formation and Andean Convergence. Mem. Geol. Soc. Am., 154:211-250.

Maris, C. R. P., Bender, M. L., Leinen, M., and Froehlich, P. N., in press. Chemical evidence for pore water advection in Mariana Trough sediments. J. Geophys. Res.

Mayer, L. A., 1980. Deep-sea carbonates: physical property relationships and the origin of high-frequency acoustic reflectors. Mar. Geol., 38:165-183.

von Damm, K. L., and Edmond, J. M., 1982. Chemistry of $21^{\circ} \mathrm{N}$ East Pacific Rise hydrothermal solutions. EOS, Trans. Am. Geophys. Union, 63:1015.

Date of Initial Receipt: 29 October 1984

Date of Acceptance: 22 November 1985 